\title{
Sex differences in primary hypertension
}

\author{
Kathryn Sandberg ${ }^{*}$ and Hong Ji
}

\begin{abstract}
Men have higher blood pressure than women through much of life regardless of race and ethnicity. This is a robust and highly conserved sex difference that it is also observed across species including dogs, rats, mice and chickens and it is found in induced, genetic and transgenic animal models of hypertension. Not only do the differences between the ovarian and testicular hormonal milieu contribute to this sexual dimorphism in blood pressure, the sex chromosomes also play a role in and of themselves. This review primarily focuses on epidemiological studies of blood pressure in men and women and experimental models of hypertension in both sexes. Gaps in current knowledge regarding what underlie male-female differences in blood pressure control are discussed. Elucidating the mechanisms underlying sex differences in hypertension may lead to the development of anti-hypertensives tailored to one's sex and ultimately to improved therapeutic strategies for treating this disease and preventing its devastating consequences.
\end{abstract}

\section{Introduction}

Sex differences in biology arise from differences in sex chromosome dosage (2X vs. $1 \mathrm{X}$ or $0 \mathrm{Y}$ vs. $1 \mathrm{Y}$ ) [1]. It is the transcription factor Sry located on the Y chromosome that causes differentiation of testes and leading to a rise in the levels of testosterone (T) in utero. Since one's sex is defined phenotypically (i.e., whether one is born with testes or ovaries), a functioning Sry leads to the birth of a male while in its absence (e.g., an XX or $\mathrm{XO}$ individual), ovaries develop and a female is born. Thus, Y dosage (0Y or $1 \mathrm{Y}$ ) dictates the hormonal milieu in utero and throughout the life span. Physiological sex differences can also arise from differences in $\mathrm{X}$ dosage $(2 \mathrm{X}$ or $1 \mathrm{X})$ as a result of differences in parental imprinting, escape from X-inactivation and X-mosacism. This review will focus not only on the impact of the gonadal hormone milieu but also on the other effects that differences in the sex chromosome complement can exert on blood pressure control. The current state of knowledge regarding sex differences in the pathophysiology of human hypertension as well as the clinical implications of studies conducted in experimental animal models of hypertension will be addressed.

Many organizations including the leading United States authority on blood pressure - the Joint National Committee on the Prevention, Detection, Evaluation and

\footnotetext{
* Correspondence: sandberg@georgetown.edu

Center for the Study of Sex Differences in Health, Disease and Aging Georgetown University, Washington, DC 20057
}

Treatment of High Blood Pressure (JNC) - define hypertension as a systolic blood pressure (SBP) $\geq 140$ or a diastolic blood pressure (DBP) of $\geq 90 \mathrm{~mm} \mathrm{Hg}$. According to the 7th and the latest report of the JNC [2], high blood pressure is divided into three categories (in $\mathrm{mm}$ Hg): Prehypertension (SBP of 120-139 or DBP between 80-89); Stage 1 hypertension (SBP of $140-159$ or DBP between 90-99); and, Stage 2 hypertension (SBP $\geq 160$ or $\mathrm{DBP} \geq 100$ ).

High blood pressure can lead to substantial morbidity by damaging the function of critical organs including the brain, heart, blood vessels and kidney [3]. Hypertension is a leading cause of stroke $[4,5]$ and can cause hypertensive encephalopathy $[6,7]$ resulting in headaches, confusion and even convulsions. Sustained hypertension can lead to hypertensive retinopathy of the eye, which untreated can lead to blindness [8]. Hypertension can cause myocardial infarction [9] and hypertensive cardiomyopathy [10]. Chronic kidney failure is often a result of hypertension, as is hypertensive nephropathy $[11,12]$. Elevated blood pressure is associated with high blood sugar. Thus hypertension could also contribute to type II diabetes [13].

Hypertension is a global health concern. One billion people worldwide have hypertension [14] and sixty five million inhabitants in the United States alone require treatment for their hypertension [15]. In fact, suboptimal blood pressure (SBP $>120 \mathrm{~mm} \mathrm{Hg}$ ) is the number one attributable risk factor for death throughout the world and it is responsible for more than $60 \%$ of cardiovascular
C Biomed Central

(c) 2012 Sandberg and Ji; licensee BioMed Central Ltd. This is an Open Access article distributed under the terms of the Creative Commons Attribution License (http://creativecommons.org/licenses/by/2.0), which permits unrestricted use, distribution, and reproduction in any medium, provided the original work is properly cited. 
disease and $50 \%$ of ischemic heart disease $[16,17]$. What is particularly problematic is that the majority of hypertensive individuals do not have their blood pressure under control $(<140 / 90 \mathrm{~mm} \mathrm{Hg})$ including nearly half of the hypertensive population in the United States [2]. A greater understanding of sex differences in the physiology and pathophysiology of blood pressure control could yield treatments that are better tailored to the individual because one's sex is taken into account. Furthermore, elucidating the mechanisms responsible for gonadal and sex chromosome effects on blood pressure could lead to the development of novel and improved antihypertensive therapeutics for treating this debilitating disease.

Hypertension can be induced by secondary causes such as chronic renal disease, pheochromocytomas or sleep apnea; however, the vast majority (>95\%) of human hypertension is due to unknown causes and is referred to as "essential" or primary hypertension [2]. Blood pressure is salt-sensitive in the majority of individuals, i.e., modulated by changes in dietary sodium intake. Salt-sensitivity is markedly more prevalent in hypertensive African Americans at 72\%, compared with a $56 \%$ prevalence in hypertensive whites [18]. This review will focus on sex differences in essential hypertension including salt-sensitive hypertension and not on the less frequent causes of hypertension.

\section{Sex differences in blood pressure across the human life span}

A wealth of blood pressure data in men and women has been collected over the years. In 1947, Boynton and Todd [19] measured blood pressure in 75,258 university students, which revealed that both SBP and DBP were significantly higher in young men than in young women [SBP/ DBP (mm Hg): men, 122/74.5 vs. women, 111/69.7]. The National Health and Nutrition Examination Survey (NHANES), which was established in the early 1960 s by the National Center for Health Statistics, a part of the Centers for Disease Control (CDC), conducts nationally representative surveys via interviews and physical examinations of the United States population. Data gathered from April 1971 to June 1974 through the NHANES I study of 28,043 individuals aged 1-74 years old revealed that sex differences in blood pressure originates in adolescence starting between the ages of 12-17, at which time, the mean SBP and DBP for boys consistently exceeded that for girls [20]. In younger children (6-11 years old), no sex differences in SBP or DBP were detected.

Between 1973-1975, one million Americans were screened in the Community Hypertension Evaluation Clinic Program [21] (Figure 1). Analysis of these data revealed that DBP was higher in men than in women in both Blacks and Whites across all age groups. White men had higher SBP than White women through their mid- sixties; however, after 65 years of age, the sex difference in SBP disappeared. Black men had higher SBP than Black women through the fifth decade of life but in older age groups, Black women had higher SBP than Black men. These racial differences in SBP across the life span may be related to differences in life expectancy. The CDC reported in October 2010 that life expectancy for non-Hispanic Black men (69.2 years) is 6.4 years shorter than non-Hispanic White men (75.6 years) [22]. Other factors could also contribute to these racial differences in blood pressure such as the rising epidemic of obesity. In this regard, it is of note that NHANES III (1988-1994) found that obesity and overweight prevalence were highest in non-Hispanic black women with more than half of this population of women aged 40 years or older being classified as obese and more than $80 \%$ as overweight [23].

Findings regarding sex differences in the prevalence of hypertension parallel the observations of sex differences in arterial blood pressure. NHANES, which surveyed data for the overall US population (excluding pregnant women, institutionalized individuals and military personnel) in all age and racial groups between 1999 and 2004 found that men regardless of race and ethnicity had a higher prevalence of hypertension than women in the 1839 age group [24] (Figure 2). Between the ages of 50-69, the prevalence of hypertension remained greater in men than women in non-Hispanic whites while this sex difference was greatly diminished in the non-Hispanic Black population and disappeared in the Mexican Americans. After the age of 70, women had a higher prevalence of hypertension across all racial groups.

Several cross-sectional studies including the above Community Hypertension Evaluation Clinic Program [21], the Hypertension Detection and Follow-up Program Cooperative Group [25] and the NHANES II [26] and NHANES III [27] suggest that the rate of the age-associated increase in blood pressure accelerates in women around the fifth and sixth decades of life and eventually exceeds that of men (Figure 2). Whether or not blood pressure in women actually surpasses men at later ages remains controversial. Blood pressure in women did not exceed that in men at any age in the 30 year longitudinal study of 5,209 healthy men and women living in Framingham, Massachusetts between 30 and 60 years of age [28], nor was blood pressure higher in women in a 30 year longitudinal study of 202 men and women from a Pittsburgh high school population [29]. Longitudinal studies enable comparing the same study population over time and thus, age-associated traits are readily observed. In contrast, while cross-sectional studies have the advantage of acquiring data on huge populations (e.g., one million Americans), the population represented in their seventies likely has different characteristics than the population represented in their forties. For instance, it is 


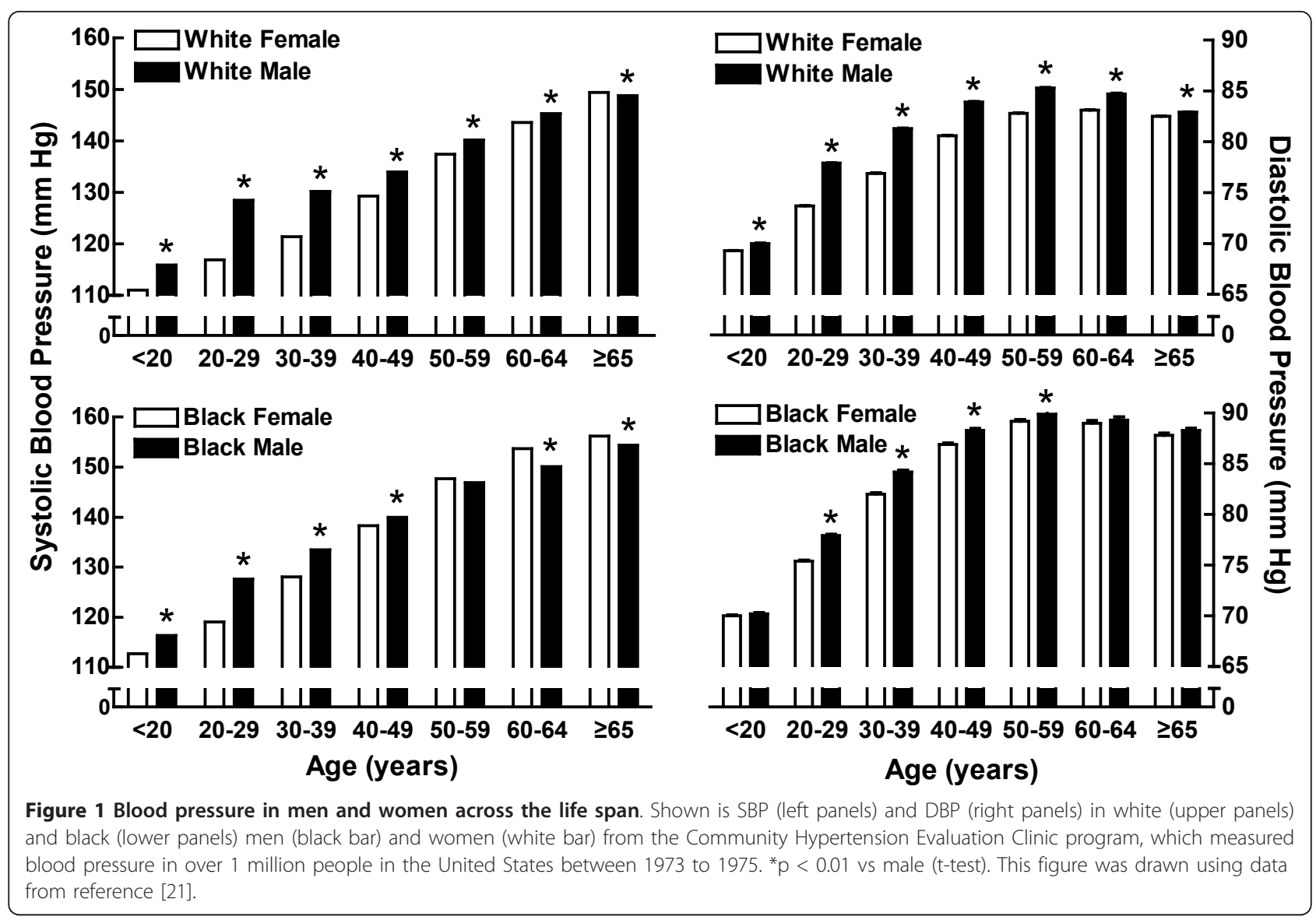

known from the Framingham study that sex differences exist in the number of deaths due to hypertension-associated cardiovascular disease; coronary events occur twice as often in men than in women [30]. Thus, comparing the prevalence of hypertension in men and women across the life span would be confounded by the changes in representation of the surviving population.

In general, epidemiological studies indicate that the prevalence of hypertension is greater in men than women regardless of race, ethnicity or country of origin. The Hypertension Detection and Follow-up Program Cooperative Group screened 158,906 persons aged 30-69 years in 14 communities between 1973 to 1974 and found that hypertension was more prevalent in men than women of either European-American or African-American ancestry [31]. A secondary analysis of the prevalence of hypertension conducted on 46 population-based studies from 22 different countries during the period of 1960-1991 found the prevalence of hypertension in most but not all studies was higher in men than women. Age may well have been a factor in the studies that did not observe a lower prevalence rate of hypertension in women than men since age was not taken into account in many of these studies and varied from all ages with some ranging from 18-79 and 20-49 and 40-79 in others [32].

While mean sex differences in arterial pressure are not huge (e.g., sex differences in SBP rarely exceed $10 \mathrm{~mm}$ $\mathrm{Hg}$ and sex differences in DBP rarely exceed $5 \mathrm{~mm} \mathrm{Hg}$ ), it is important to note that an increase of $10 \mathrm{~mm} \mathrm{Hg} \mathrm{SBP}$ doubles the risk of developing cardiovascular disease while a drop of $5 \mathrm{~mm} \mathrm{Hg}$ in SBP results in a 14\% reduction in mortality due to stroke and a $9 \%$ reduction in mortality due to coronary heart disease [2]. Therefore, the observation that men have higher blood pressure than women, at least up to the fifth decade of life, has significant implications for pathophysiology. Moreover, deciphering the molecular mechanisms underlying sex differences in hypertension could ultimately lead to the discovery of new and improved antihypertensive treatments for both men and women.

\section{Sex differences in blood pressure in animals}

Sex differences in blood pressure were observed in animals as early as 1962. Van Liere studied mean arterial pressure (MAP) (i.e., the perfusion pressure exerted on the organs) in 147 adult dogs and found an $8 \mathrm{~mm} \mathrm{Hg}$ difference in MAP between the males and females [33] 


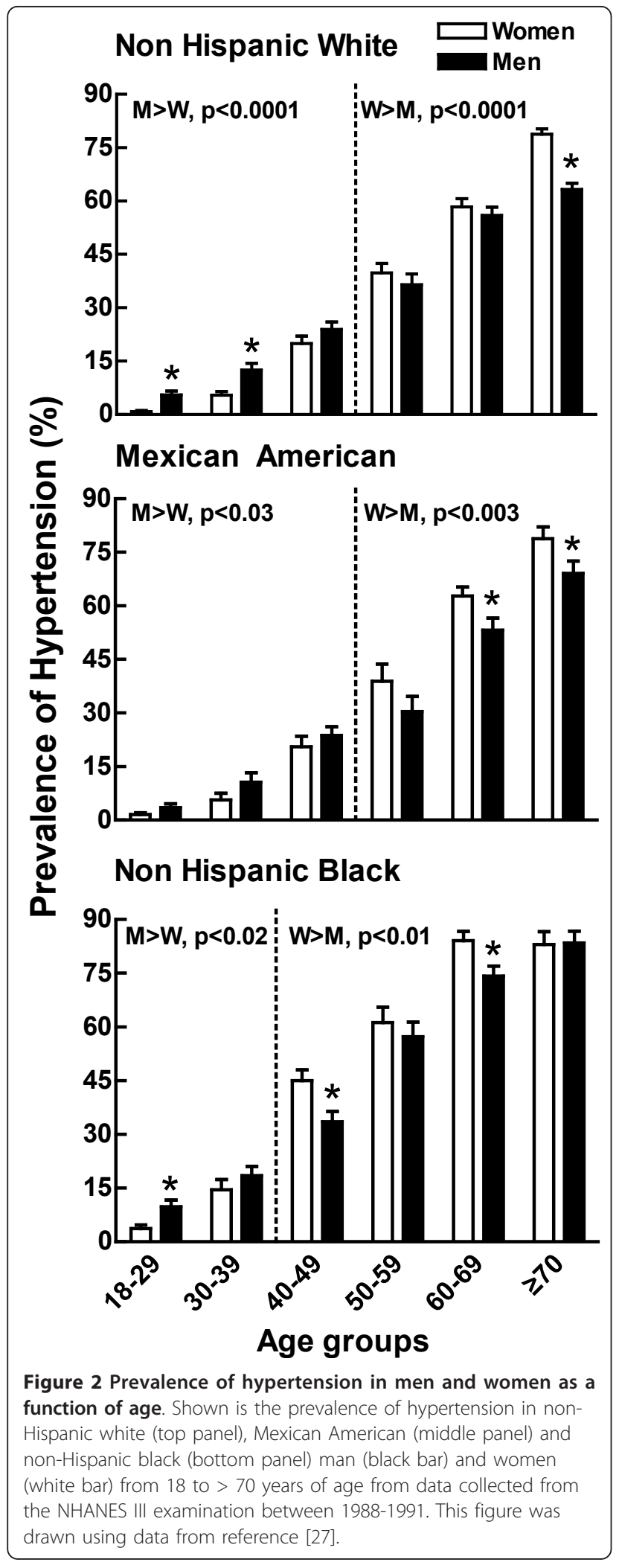

(Figure 3). When MAP is graphed as a percent of this dog population by sex, the data reveal a higher

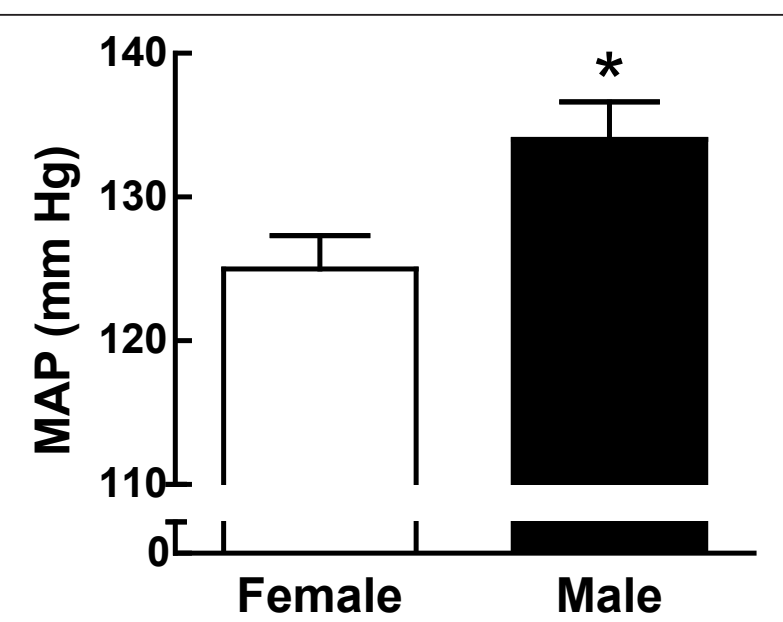

Figure 3 Mean arterial pressure in female and male dogs. Shown is the MAP in female $(n=80)$ and male $(n=67)$ street dogs of unknown age. ${ }^{*} p<0.05$ vs female (t-test). This figure was drawn using data from reference [33].

percentage of the female population than the male population at the lowest ranges $(60-119 \mathrm{~mm} \mathrm{Hg})$, while at the highest ranges (160-199 $\mathrm{mm} \mathrm{Hg}$ ), the population was primarily male [33]. The MAP data in this dog population of unknown age mirrors the lower blood pressure observed in normotensive women compared to normotensive men (Figure 1) and the lower prevalence of hypertension in women compared to men in the 1849 years old age group (Figure 2). Based on the fact that this study investigated blood pressure in street dogs, it is more likely this dog population was comparable to the 18-40 human age group, rather than the 50-70+ human age group, given that street dogs are not likely to realize their full life expectancy due to food constraints, disease, fatal accidents and abuse.

This sex difference in blood pressure is not restricted to the mammalia class of animals (mammals) as it is also observed in Aves (birds). A study of blood pressure from chick to full grown adult in domestic fowl (Gallus gallus) showed that male chickens had greater SBP and DBP than the females [34] (Figure 4). This finding in birds is particularly intriguing because sex chromosome dosage in birds is opposite to that found in mammals; the male has two of the same sex chromosomes (designated $\mathrm{ZZ}$ in birds) while it is the female that has two different ones (ZW) [1]. What is similar between mammals and birds of the same sex is that their gonadal hormone milieu impacts blood pressure similarly in both animal classes. Birds, therefore serve as a valuable and informative experimental model to investigate the mechanisms underlying sex differences in blood pressure control since they offer unique opportunities to study dosage compensation in the presence of an inverse gonadal hormone milieu from that seen in mammals. 


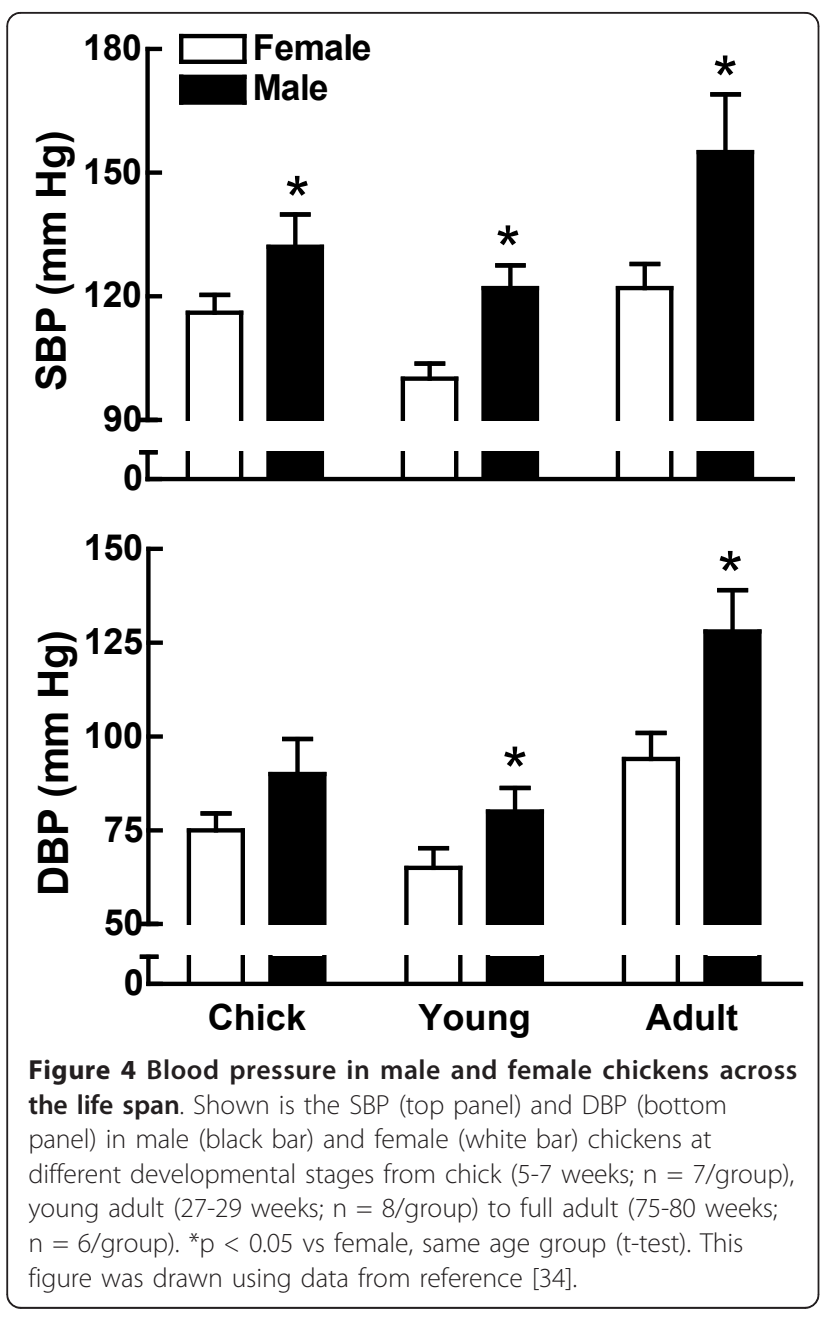

Sex differences in blood pressure in experimental models of hypertension and the implications for human hypertension

\section{Renin-angiotensin system}

The renin angiotensin system (RAS) plays a crucial role in the control of blood pressure and inhibitors of angiotensin II (Ang II) synthesis and Ang II signaling via the angiotensin type 1 receptor $\left(\mathrm{AT}_{1} \mathrm{R}\right)$, are widely used to treat hypertension. Ang II infusion is a well studied model of induced hypertension and has been used in rabbits [35], dogs [36], and rodents [37]. In this model, MAP was $20-30 \mathrm{~mm} \mathrm{Hg}$ higher in males compared to females after Ang II was infused into the inbred C57BL/6J [38] and outbred MF1 [39] mouse strains as well as in Sprague Dawley rats [40]. In fact, there are doses of Ang II in these animals that cause hypertension in the male (defined as a MAP $\geq 135 \mathrm{~mm} \mathrm{Hg}$ ) while leaving the female normotensive. These sex differences can thus be exploited for determining the signaling pathways critical for the development of hypertension and the mechanisms that protect against hypertension.
Aldosterone infusion is another model of induced hypertension that involves the RAS and similarly to the Ang II infusion model, MAP can be increased in male rats $(\Delta 26 \mathrm{~mm} \mathrm{Hg})$ under conditions where no significant differences in blood pressure are observed in the females [41] (Figure 5). Full dose response studies for the Ang IIand aldosterone-induced models of hypertension will shed light on whether male-female differences in blood pressure are due to sex differences in the dose that elicits the maximum MAP response (Emax) or in the effective concentration that achieves fifty percent of the maximum response $\left(E_{50}\right)$; however, ceiling effects may confound such studies since the frequency of strokes and seizures resulting in the animal's death markedly increases with advancing hypertension.

Nitric oxide plays a fundamental role in the control of blood pressure [42]. Inhibition of its synthesis by chronically administering $\mathrm{N}^{\omega}$-nitro-L-arginine methyl ester (L-NAME) was shown to cause persistent hypertension [43]. When normotensive Wistar rats were treated with LNAME, the males exhibited $27 \mathrm{~mm} \mathrm{Hg}$ higher MAP than their female counterparts [44] (Figure 5). Like the Ang II and aldosterone infusion models, the hypertension induced by inhibiting nitric oxide synthesis can be attenuated by antagonists of the $\mathrm{AT}_{1} \mathrm{R}$ [45] or angiotensin converting enzyme inhibitors $[46,47]$. The hypertension that develops can even be reversed by inhibiting Ang II synthesis after the hypertension is established [48]. At this point, it is not known whether the RAS plays a permissive or causative role in L-NAME-induced hypertension; however, the finding that all three of these induced models of hypertension are RAS-dependent supports the concept that sex differences in the regulation of the RAS contribute to sex differences in control of arterial blood pressure in these models. In fact, our lab and others have postulated that the lower blood pressure observed in females in RAS-dependent models of hypertension is due to the ability of the female (in comparison to the male) to achieve lower plasma and tissue levels of Ang II (e.g., by increased catabolism of Ang II $[39,49])$ and/or through maintaining lower numbers of functional $\mathrm{AT}_{1} \mathrm{Rs}$ in the membrane of key target tissues like the kidney [50], which would result in less $\mathrm{AT}_{1} \mathrm{R}$-mediated vasoconstrictor action in the female compared to the male (see excellent review by Sullivan [51]). These findings of sex differences in the activity of the RAS in experimental animal models of hypertension are supported by clinical studies. Renin is is the rate limiting step in Ang II synthesis and women are reported to have lower prorenin and renin levels than men [52]. Furthemore, an interesting paper by Mirza et al. [53] suggests the combination of $E_{2}$ with an $\mathrm{AT}_{1} \mathrm{R}$ antagonist is more effective than either alone at lowering blood pressure in postmenopausal hypertensive women. These studies highlight the need to fully understand the sex differences 


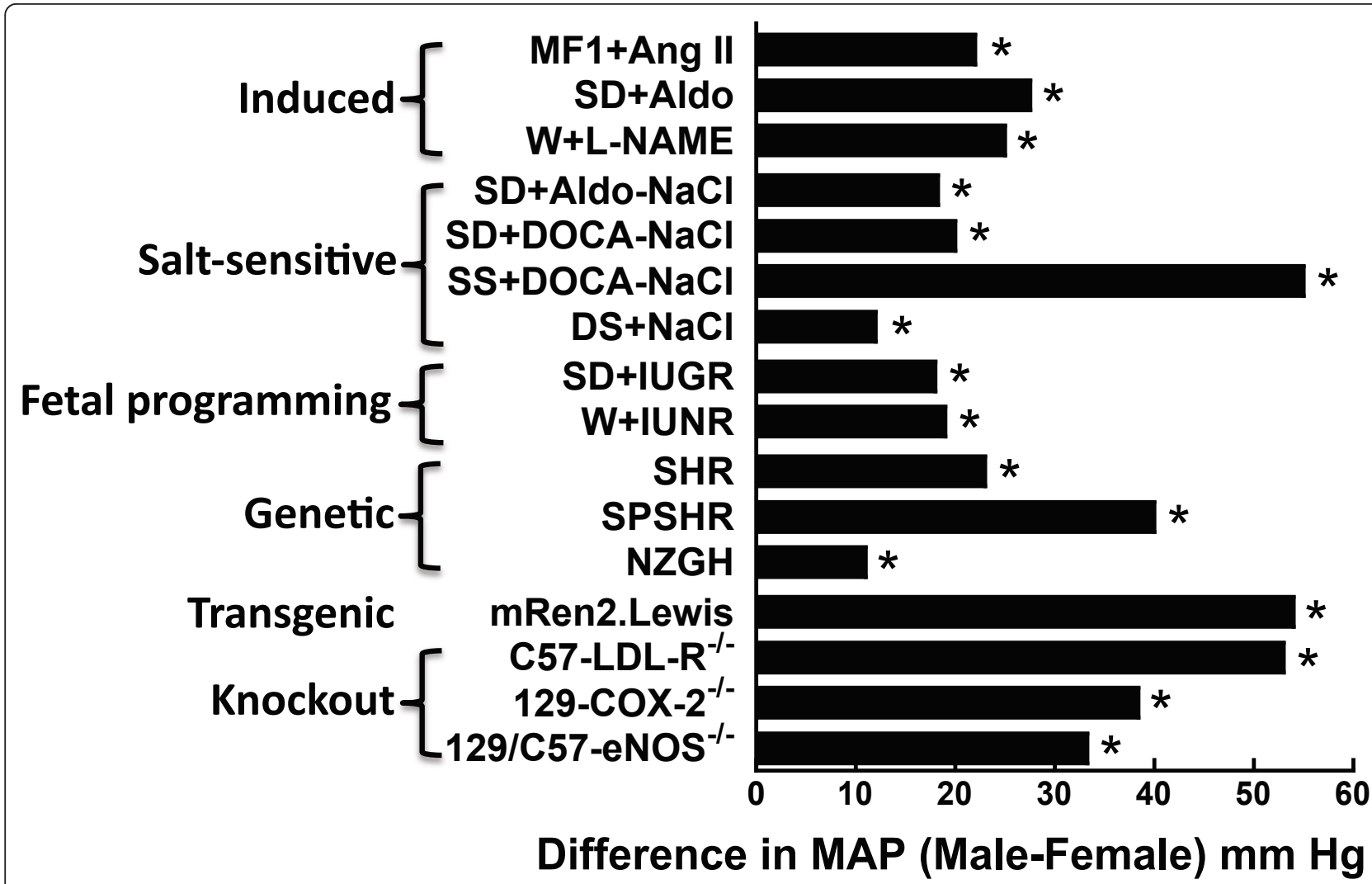

Figure $\mathbf{5}$ Sex differences in arterial blood pressure in experimental models of hypertension. Shown is the difference in arterial blood pressure between males and females in animal models of hypertension including Ang II infusion in MF1 mice (MF1+Ang II) [39] a aldosterone infusion in Sprague Dawley (SD) rats (SD+Aldo) [41] $]^{\mathrm{a}}$ and L-NAME-treated Wistar rats (W+L-NAME) [44] $]^{\mathrm{C}}$. Salt-sensitive models include SD rats maintained on a $1 \%$ $\mathrm{NaCl}$ diet and infused with aldosterone (SD+Aldo-NaCl) [54] $]^{\mathrm{a}}$ or deoxycorticosterone acetate (SD+DOCA-NaCl) [55] $]^{\mathrm{C}}$ and, DOCA-NaCl treated Sabra saltsensitive rats (SS+DOCA-NaCl) [60 ${ }^{c}$ and $\mathrm{DS}$ rats maintained on $8 \% \mathrm{NaCl}(\mathrm{DS}+\mathrm{NaCl})[57]^{\mathrm{a}}$. Fetal programming models of hypertension include rats subjected to intrauterine growth restriction (SD+IUGR) [64] ${ }^{\mathrm{a}}$ and intrauterine nutrition restriction (W+IUNR) [65] $]^{\mathrm{c}}$, respectively. Genetic models include

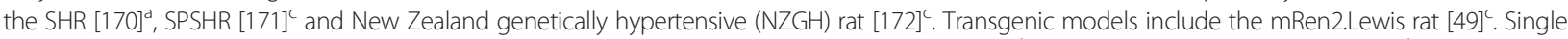
gene knock out models of hypertension include the low density lipoprotein receptor (C57-LDL-R $\left.{ }^{-1}\right)[73]^{c}$, cyclooxgenase-2 $\left(129-\mathrm{COX}-2^{-1}\right)[74]^{\mathrm{C}}$ and endothelial nitric oxide synthase (129/C57-eNOS ${ }^{-1}$ ) [76 ${ }^{\mathrm{b}}$ on the C57BL/6, 129Sv and 129Sv/C57BL/6J background strains, respectively. ${ }^{*} \mathrm{p}<0.05$, male vs female (see cited references for experimental and statistical details of individual studies). Note, studies measuring MAP by radiotelemetry ${ }^{a}$ were preferentially cited over studies using indwelling catheters ${ }^{b}$ or those reporting SBP determined by tail plethysmography ${ }^{c}$.

in the mechanisms of blood pressure control to achieve optimal treatment regimens for men and women.

\section{Diet and blood pressure}

As discussed above, blood pressure can also be raised by increasing dietary sodium. In salt-resistant individuals, the increase in MAP may only be a couple of $\mathrm{mm} \mathrm{Hg}$, whereas in salt-sensitive individuals, this salt-dependent increase in arterial blood pressure can be substantial [18]. Experimental models of salt-sensitive hypertension include chronic treatment with aldosterone [54] or deoxycorticosterone acetate (DOCA) [55] in the presence of $1 \% \mathrm{NaCl}$ in the drinking water. In both these induced models, the effect of dietary sodium on MAP was more than $20 \mathrm{~mm} \mathrm{Hg}$ higher in the male than in the female (Figure 5).

The Dahl salt-sensitive (DS) rat is the most widely studied genetic model of salt-sensitive hypertension and was derived from Sprague Dawley rats by inbreeding based on their susceptibility or resistance to a high sodium chloride (HS) $(7 \% \mathrm{NaCl})$ diet [56]. Maintained on a low sodium chloride (LS) diet $(0.15 \% \mathrm{NaCl})$, these animals remain normotensive for many weeks; however, raising the dietary sodium percent by $1-8 \%$ induces hypertension in both sexes in a graded manner though to a greater extent in the male than the female [57] (Figure 6). This positive relationship between the sex difference effect size (difference in MAP between male \& female) and the magnitude of the hypertension is also observed in the Ang II and aldosterone infusion models (Figure 7). In other words, as the degree of hypertension increases in the male, the magnitude of the sex difference in MAP increases. Some studies suggest that even when blood pressure is identical between males and females, the end organ damage is far greater in the male than in the 


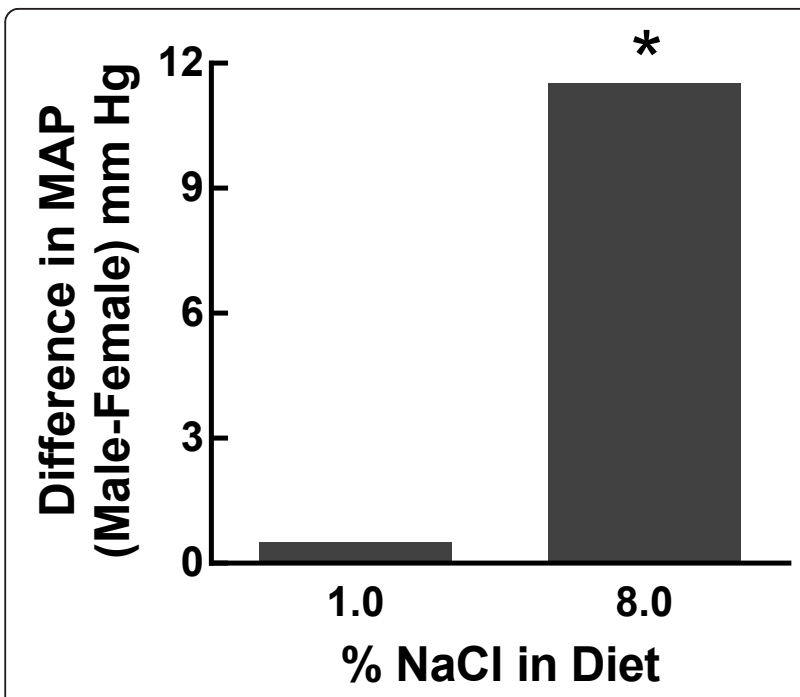

Figure 6 Effect of dietary sodium on the sex differences in MAP in the DS rat. Shown is the difference in MAP between males and females in the DS rat as a function of dietary sodium; $\mathrm{p}$ $<0.05$, male vs female (2-way ANOVA, sex, time). This figure was drawn using data from reference [57].

female. For instance, the JNC7 reports that the age-associated increase in cardiovascular disease risk is markedly greater in men than women at identical SBP and DBP [2]. We have found similar results in the renal wrap model of hypertension. At equivalent MAP, the male rats exhibited far more renal injury than the females as measured by the glomerular sclerotic index, mean glomerular volume, and proteinuria [58]. These clinical and experimental findings suggest sex differences not only exist in the incidence and magnitude of hypertension but also in the adverse effects of hypertension on end organ damage.

At the low end of the Ang II (50 ng/ $\mathrm{kg} / \mathrm{min}$ ) dose response curve, a telemetry study conducted in Sprague Dawley rats found that Ang II actually decreased MAP in the females but had no effect in the males [59]. This blood pressure lowering effect of low dose Ang II was shown to be mediated by the angiotensin type 2 receptor $\left(\mathrm{AT}_{2} \mathrm{R}\right)$ since an antagonist of the $\mathrm{AT}_{2} \mathrm{R}$ prevented this effect. The authors concluded that the lower expression of the $\mathrm{AT}_{2} \mathrm{R}$ in male target tissues (e.g., the vasculature and kidney) compared to the female made males less able to realize the benefits of the $\mathrm{AT}_{2} \mathrm{R}$-mediated blood pressure lowering effects. These interesting findings emphasize the critical importance of taking into account the sex of the animal when investigating physiological mechanisms of $\mathrm{AT}_{2} \mathrm{R}$ action. Furthermore, this study demonstrates how mechanisms modulating blood pressure in one sex can not necessarily be extrapolated to the opposite sex.

The Sabra salt-sensitive (SS) rat was developed using a similar strategy to that used to derive the DS rat [60];

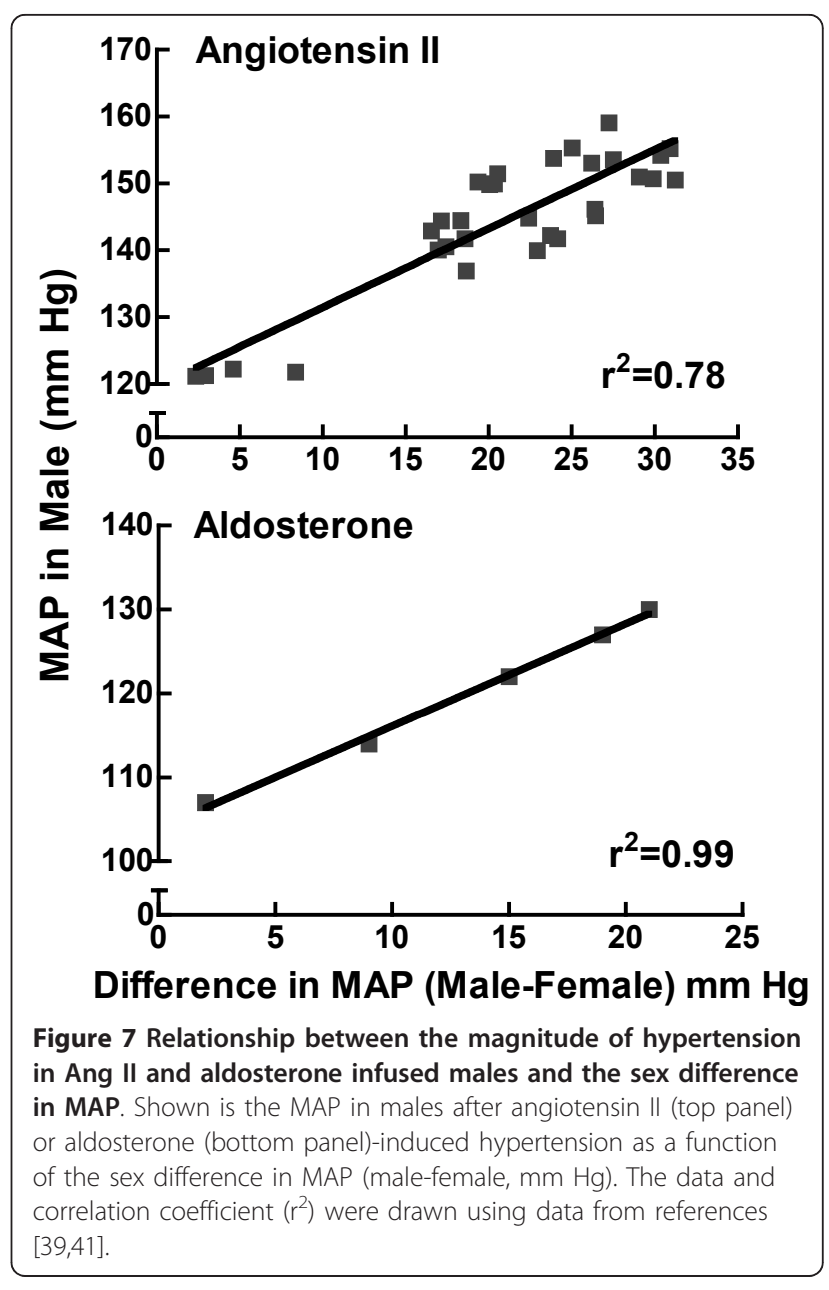

however, instead of a HS diet, the SS rat was selected based on susceptibility or resistance to DOCA-salt. Similarly to the DS rats, the males have nearly $30 \mathrm{~mm}$ $\mathrm{Hg}$ higher MAP than the females (Figure 5). These findings of sex differences in salt-sensitivity are also seen in humans. Wilson et al. [61] examined blood pressure responses to changes in dietary sodium in 135 male and female adolescents and found that the girls lowered their blood pressure to a greater degree than the boys after dietary sodium was reduced. Furthermore, when dietary sodium was increased, blood pressure was raised to a greater extent in the boys.

It is not just sodium in the diet that adversely impacts blood pressure, high fat [62] and high fructose [63] diets are also associated with increased MAP. In both cases, the female is protected from the diet-induced hypertension compared to the male. Adverse fetal environments (also known as fetal programming) can induce hypertension in offspring. Intrauterine growth restriction induced by placental insufficiency in late gestation results in hypertensive male offspring; at 12 weeks of age, the MAP reached $158 \mathrm{~mm} \mathrm{Hg}$ in the males, a $23 \mathrm{~mm} \mathrm{Hg}$ increase 
over the control offspring, whereas the blood pressure in the females marginally increased by $13 \mathrm{~mm} \mathrm{Hg}$ [64] (Figure 5). Intrauterine nutrition deficiency, a model in which the pregnant dams are fed $50 \%$ of a normal dietary caloric intake during the gestational period, result in marked hypertension in the male offspring $(155 \mathrm{~mm} \mathrm{Hg}$ SBP) whereas the females become only mildly hypertensive (135 mm Hg SBP) [65] (Figure 5).

The spontaneously hypertensive rat (SHR) was established in the 1960s by selectively breeding Wistar-Kyoto rats with high blood pressure [66] and is currently the most widely studied model of primary hypertension [67]. The stroke prone SHR (SPSHR) was developed using a similar strategy with the prevalence of stroke used to select the strain [68]. In both the SHR [69] and the SPSHR [70], the males develop hypertension at earlier ages than the females and the severity of the hypertension is greater in the males (Figure 5).

The higher blood pressure observed in the males is also found in genetic models of hypertension that over express or under express a specific gene. Over expression of the mouse Ren-2 gene in various rat tissues was the first example of a transgenic model of hypertension [71]. These (mRen2)27 rats exhibit fulminating hypertension that is lethal in the homozygous state if not treated with antihypertensive medications. When these rats were backcrossed onto the Lewis inbred strain creating the congenic mRen2.Lewis rat, the hypertension was less severe, the rats survived and sex differences in MAP became apparent [72] (Figure 5).

For the most part, the factor of sex has been poorly investigated in gene knockout $(\mathrm{KO})$ models of hypertension. In the ones that have measured blood pressure in both sexes, arterial pressure was higher in the males than the females including mice deficient in the low density lipoprotein receptor [73], cyclooxygenase-2 [74], the $\alpha 1$ subunit of soluble guanylate cyclase $\left(\mathrm{sGC}^{-1-} \mathrm{1}^{-1}\right)[75]$ and endothelial nitric oxide synthase [76]. Unfortunately, blood pressure has only been reported for males in hypertensive mice lacking atrial natriuretic factor, which leads to salt-sensitive hypertension [77] and mice lacking the atrial natriuretic type A receptor, which are hypertensive but not salt-sensitive [78]. Further missed opportunities for understanding sex differences in hypertension include mice lacking the CXC chemokine receptor 3 [79] and $11 \beta$-hydroxysteroid dehydrogenase type 2 [80] since only male blood pressure has been reported thus far.

Studying sex differences in these various experimental models of hypertension could provide valuable clues into the intrinsic mechanisms that govern sex differences in blood pressure. For instance, if a sex difference in blood pressure was not found in a particular $\mathrm{KO}$ animal after hypertension was induced, then that specific gene would be implicated in the mechanisms contributing to sex differences in that model of hypertension. The corollary experiment implicating a specific gene in the sex differences in hypertension would include mice over-expressing a candidate gene.

\section{Blood pressure measurement procedures: Implications for the study of sex differences}

Radiotelemetry is considered the gold standard for measuring blood pressure in animals [81]. A radiotransmitter is installed near the aorta, which enables MAP to be followed continuously both day and night in a conscious freely moving animal from minutes to several months without the stress associated with restraint [82]. This automatic feature of radiotelemetry is particularly appreciated when studying blood pressure in rodents since rodents spend their normal waking hours during the night. Blood pressure can also be inexpensively measured by tail-cuff plethysmography, which involves placing the mouse or rat in a tube and measuring the blood pressure in the extended tail; however, this restraint can stress the animal [83]. Moreover, the tail-cuff procedure frequently involves heating the animal to increase blood flow in the tail artery, which exerts additional stress as well as introduces a measurement artifact across subjects [84].

The stress component of tail-cuff measurements including immobilization and heat can raise blood pressure. A study in normotensive WKY and hypertensive SHR showed that SBP was approximately $30 \mathrm{~mm} \mathrm{Hg}$ higher when measured by tail-cuff [WKY, $162 \pm 5$; SHR, $207 \pm 5$, $\mathrm{mm} \mathrm{Hg}$ ] than by telemetry [WKY, $131 \pm 1$; SHR, $178 \pm 6$, $\mathrm{mm} \mathrm{Hg}$ [ [85]. A study in prenatally malnourished rats showed that the blood pressure increase induced by a noxious odor was augmented by the stress of the tail-cuff procedure itself [86]. The stress from tail-cuff can also affect the response to drugs. Hydralazine had an approximately 2 -fold greater hypotensive effect on the SBP when measured by tail-cuff compared to telemetry, indicating that the antihypertensive effects of some drugs may be influenced by the level of stress the animal is experiencing [86]. Sullivan et al. [87] showed that female endothelin B receptor-deficient rats maintained on a HS (8\%) diet for two weeks had $12 \mathrm{~mm} \mathrm{Hg}$ higher SBP than males when measured by tail-cuff; however, in a later study when radiotelemetry was used to measure MAP in these animals, the females no longer had higher blood pressure than the males (David M. Pollock, personal communication). The authors then found that the females exhibited a greater rise in blood pressure in response to acute air jet stress compared to the males, suggesting that in endothelin $B$ receptor-deficient rats, the females were more responsive than the males to acute stress. These findings suggest that the higher arterial pressures observed in the female rats detected by tail-cuff was due to their greater responsivity to the stress of immobilization compared to the male rats. 
Blood pressure can also be measured under anesthesia using carotid arterial cannulation; however, blood pressure measured under anesthesia is typically $10-20 \mathrm{~mm}$ $\mathrm{Hg}$ lower than when measured in conscious freely moving animals $[88,89]$. This observation demonstrates that anesthesia in and of itself can affect arterial pressure and thus differential responses by males and females to anesthetics [90] could confound interpretation of blood pressure studies between the sexes.

In people, blood pressure is typically measured using a stethoscope and sphygmomanometer after an individual has been sitting calmly for a few minutes because blood pressure can be elevated by physical activity and emotional stress. In fact, there is a documented phenomenon called "white coat hypertension", which is defined as a normotensive individual who exhibits increased SBP and DBP of at least $20 \mathrm{~mm} \mathrm{Hg}$ and $10 \mathrm{~mm} \mathrm{Hg}$, respectively, in the presence of a health care provider. Multivariate analysis of 5,716 patients in Ireland over a 22 year period demonstrated that females have a higher prevalence of white coat hypertension than males [91]. A higher prevalence of white coat hypertension in women was also observed in 2,462 patients in Morocco [92] and in a Korean population of 967 patients [93]. White coat hypertension is associated with increased sympathetic activity $[94,95]$, decreased parasympathetic-modulation $[94,96]$, increased activity of the RAS [95], higher scores on measures of conditioned anxiety [97] and higher levels of adrenocorticotrophic hormone and cortisol after challenge with corticotropin releasing hormone [98]. Together, these data suggest that arterial pressure in women exhibits more hypothalamic-pituitary-adrenal hypersensitivity to stressors than arterial pressure in men.

\section{Sex differences in the genetic basis for salt-sensitive hypertension}

Sex differences in the genetic basis for salt-sensitivity was observed in the Sabra salt-sensitive (SS) rat by linkage analysis in segregating populations derived from the SS (a.k.a. SBH/y) and Sabra salt-resistant strain (SR a.k.a. $\mathrm{SBN} / \mathrm{y}$ ). Whereas two quantitative trait loci (QTL) for salt-sensitive blood pressure were found on chromosome 1 in the male (SS1a and SS1b), in the female only the SS1b was found to be a QTL [99] (Figure 8). Moreover, a QTL on the X chromosome was identified only in the female [100]. Consomics were then constructed in which these two QTL on chromosome 1 from the SR rat were introgressed into the SS genetic background; however, these studies failed to show sex differences in the QTL [60].

Consomics have also been used to study the genetic basis of hypertension in the DS rat. Twenty two consomic strains were generated in which individual chromosomes from the Brown Norway salt-resistant rat were

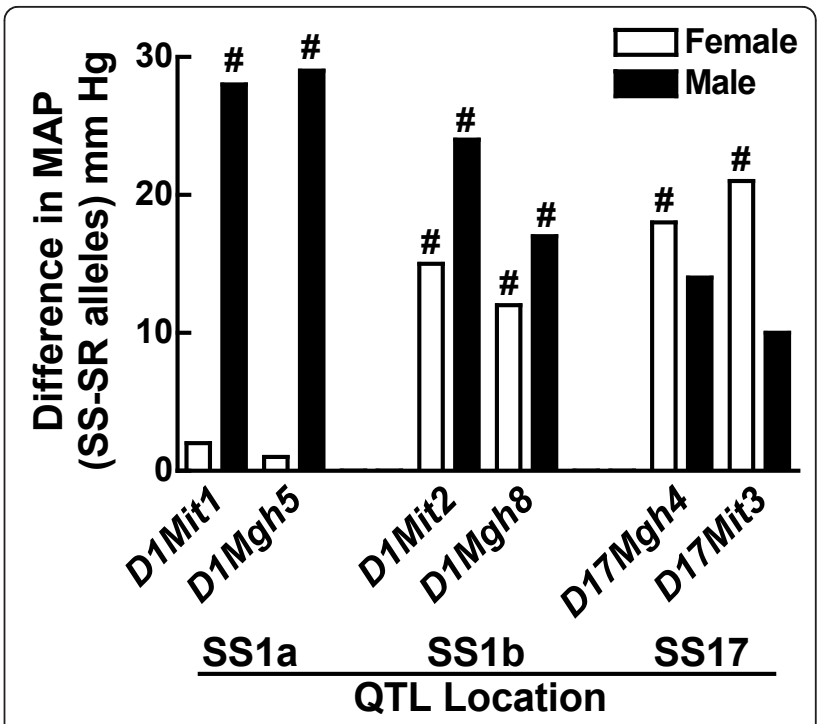

Figure 8 Sex differences in QTL locations of salt-sensitive hypertension in the SS rat. Shown is the difference in MAP between the SS rat and rats in which SS alleles were introgressed into female (white bar) and male (black bar) salt-resistant rats (SR alleles) at the SS1a, SS1b and SS17 QTL locations. \#p < 0.05 vs SS, same sex. This figure was drawn using data from reference [99].

introgressed into the DS (SS/Mcwi) genetic background. MAP was measured in both male and female rats fed a high-salt $(8.0 \% \mathrm{NaCl})$ diet for 3 weeks, and was found to be significantly greater in the male and female $(177 \pm 3$ and $160 \pm 7 \mathrm{mmHg}$, respectively) SS/Mcwi rat than in the male and female $(111 \pm 1$ and $112 \pm 3 \mathrm{mmHg}$, respectively) Brown Norway rats. Similarly, MAP was higher in males than females in certain consomic strains. Mattson et al. [101] found that substitution of chromosomes 1, 5, 7, 13, 16 and 18 from the Brown Norway onto the DS background attenuated the development of hypertension in male rats (Figure 9). In female rats, substitution of chromosomes 1 and 5 also decreased blood pressure but not chromosomes 7, 13, 16 or 18 (Figure 8 ). These findings demonstrate that the genetic basis of salt-sensitivity in the DS rat is distinctly different between males and females and this research also emphasizes the value of consomics for dissecting the genetic basis of sex differences in the control of blood pressure.

\section{Effect of gonadal hormones on blood pressure Ovaries and $17 \beta$-estradiol}

It has been difficult to disentangle the effects of ovarian function on arterial pressure in women from those of aging because ovarian hormone loss is an age-associated event. Cross-sectional studies (Figures 1 \& 2) suggest the rate of the age-associated rise in arterial pressure increases around the onset of menopause (i.e., 51 years 


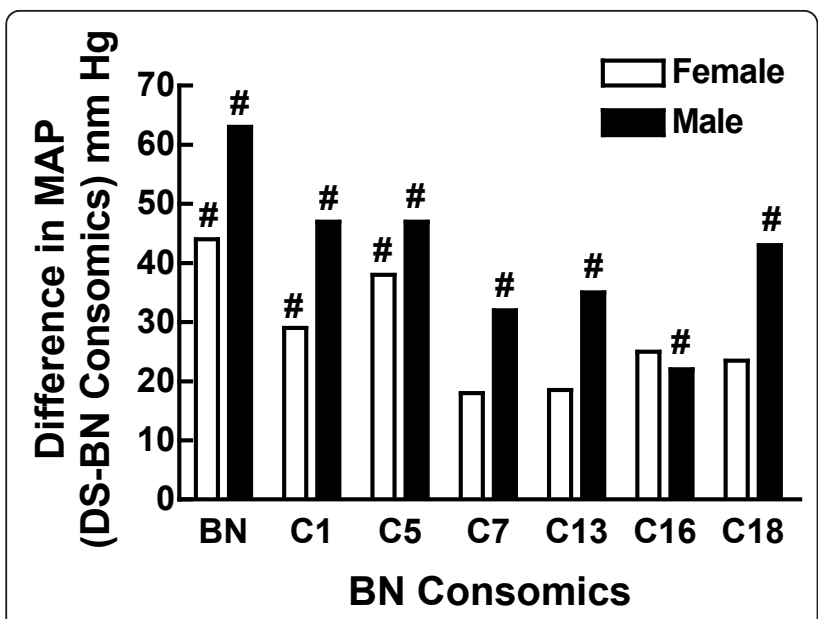

Figure 9 Sex differences in the chromosome location of saltsensitive hypertension in the DS rat. Shown is the difference in MAP between the DS rat and the salt-resistant Brown Norway (BN) rat or DS consomics in which chromosomes (C) 1, 5, 7, 13, 16 and 18 were substituted with the respective BN chromosomes in male (black bar) and female (white bar) rats. Note that the maximum difference in salt-sensitivity is expected to be between the DS and $B N$ rats. \#p $<0.05$ vs DS, same sex. This figure was drawn using data from reference [101].

of age) and prospective population studies show that postmenopausal women have higher arterial pressure than age-matched premenopausal women [102-104]; however, inferences from these studies are limited because the populations within the groups compared are not likely to differ solely on the basis of age of menopause onset.

Comparing arterial pressure between young premenopausal women and women with premature ovarian failure provides another way to assess ovarian hormone loss on blood pressure since premature ovarian failure typically presents at 27 years of age. Women with premature ovarian failure have a higher incidence of hypertension than age-matched premenopausal women suggesting ovarian hormone loss raises arterial pressure independently of the effect of aging on blood pressure. These studies, however, are confounded by the possibility that premature ovarian failure represents an acceleration of the aging process (see review by Pal \& Santoro [105]).

Turner syndrome provides a window into the blood pressure effects of ovarian function at an even earlier age since girls with Turner syndrome exhibit ovarian hormone deficiency during puberty. Compared to published population standards in girls, girls with Turner syndrome have higher blood pressure, a higher incidence of abnormal blood pressure circadian rhythms, and a higher incidence of idiopathic hypertension even in the absence of aortic coarctation, renal abnormalities or chronic urinary track infections $[106,107]$. Turner girls do not have a complete double X chromosomal complement. Therefore, comparing arterial pressures in girls with and without Turner syndrome is confounded by sex chromosome complement differences.

Longitudinal studies investigating the relationship between arterial pressure and the age of menopause onset have not demonstrated an effect of menopause on arterial pressure that is distinct from the effect of aging. Hjortland et al. [108] conducted a 5 year longitudinal study in a cohort of 1686 women who were 40-41 years old. van Beresteyn et al. [109] followed 193 perimenopausal women between 49 to 56 years of age for over 10 years and Mathews [110] examined blood pressure in 541 healthy premenopausal women 42-50 years of age for approximately $2 \& 1 / 2$ years. While none of these longitudinal studies detected an effect of menopause on arterial pressure that was distinct from aging, following changes in blood pressure in women longitudinally could have been confounded by antihypertensive medications since it is unethical to withhold antihypertensive medicine in hypertensive subjects. While it is clear that arterial blood pressure increases both with aging and ovarian hormone dysfunction in women, it is not known to what extent the mechanistic pathways of these two hypertension-associated factors overlap. Increased salt-sensitivity may be a mechanism that contributes to postmenopausal hypertension; however, whether or not postmenopausal women are more salt-sensitive than premenopausal women remains unresolved. As noted above, it is difficult to tease out age effects in women from effects due to changes in the ovarian hormonal milieu; however, much can be learned from experimental animal models.

The mRen2.Lewis rat exhibits salt-sensitive hypertension, which was not found to be magnified by ovariectomy [111]; however, SBP was measured by tail-cuff in this study and thus, the possibility remains that restraint stress due to the measurement method confounded these findings. Furthermore, the SBP is so high in the ovariectomized mRen2.Lewis rat maintained on a HS diet for 15 weeks (approximately $230 \mathrm{~mm} \mathrm{Hg}$ ) that the SBP may have reached a ceiling effect (i.e., the SBP just couldn't get any higher without the animal's demise). The effects of ovariectomy on salt-sensitivity have also been examined in the SHR [112] and DS rat [57]. In these models, the salt-sensitive component ( $\triangle$ MAP HS-LS) was found to be amplified by ovariectomy (Figure 10) indicating that the loss of ovarian hormones increases salt-sensitivity. It will be important to determine how similar these findings are to other animal models of salt-sensitivity.

Much can be learned by comparing models in which ovariectomy had and did not have an effect on arterial pressure. While ovariectomy increased arterial pressure in several animal models of hypertension including Ang II- [38,39] and DOCA- [54] infusion and the DS [113] and mRen2.Lewis [111] rats (Figure 11), ovariectomy did not raise arterial pressure in the SHR on a normal 


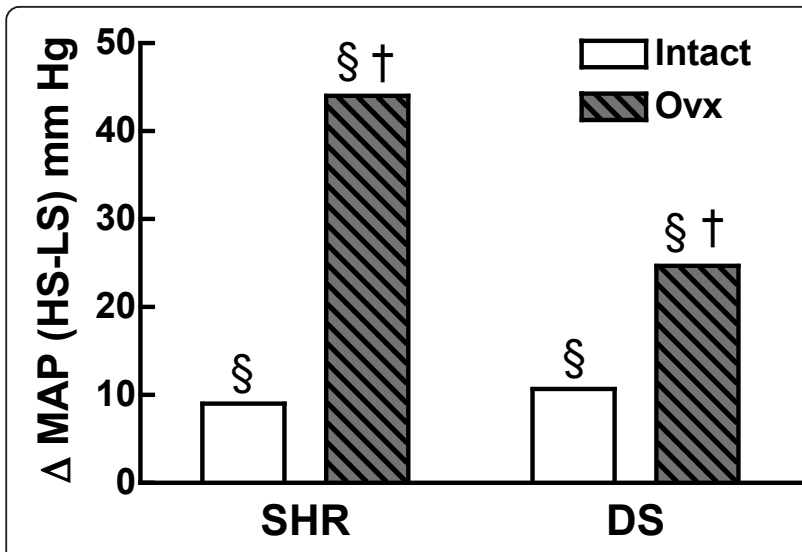

Figure 10 Effect of ovariectomy on salt-sensitivity. Shown is the difference in MAP between $\mathrm{HS}(8 \% \mathrm{NaCl})$ and LS diets $0.15-0.60 \%$ $\mathrm{NaCl}$ in the intact (white bar) and ovariectomized (Ovx) (striped bar) SHR [112] and DS rat [57]. $\$ p<0.05$ vs Intact, same rat strain, same dietary sodium; $\uparrow p<0.05$, HS vs LS, same rat strain, same gonadal state (see cited references for experimental and statistical details of individual studies).

sodium chloride diet [112] or the Wistar rat treated with the nitric oxide synthase inhibitor, L-NAME [44]. For instance, does the finding that ovariectomy has no effect on arterial pressure in the L-NAME Wistar model suggest that ovariectomy elicits its arterial pressure raising effects by reducing nitric oxide in key target tissues such as the kidney? This possibility could be addressed by comparing bioavailable nitric oxide levels and activity in the kidneys in these various models before and after ovariectomy. Taken together, these studies indicate that the presence or absence of ovarian hormones is not the only factor that underlies sex differences in blood pressure given the mixed findings regarding the effect of ovariectomy on arterial pressure (Figure 5).

To address ovarian hormone regulation of blood pressure, most investigators have compared intact animals with ovariectomized animals treated with and without $17 \beta$-estradiol $\left(E_{2}\right)$ treatment. $E_{2}$ treatment prevented the blood pressure raising effects of ovariectomy in the Ang II- [114] and DOCA- [54,115] infused models as well as in the mRen2.Lewis rat, the DS rat on both LS [82] and HS [116] diets and the SHR on a HS diet [112]. The consistency of the ability of $E_{2}$ to prevent the blood pressure raising effects of ovariectomy across these distinct experimental models of hypertension, suggests the mechanisms by which $\mathrm{E}_{2}$ loss raises blood pressure are robust and highly conserved and thus support the conclusion of cross-sectional studies showing that menopause increases arterial pressure in women.

Most experimental studies of $E_{2}$ depletion and replacement on arterial pressure have been conducted in young animals. Therefore, it has been difficult to isolate effects of $E_{2}$ deficiency from aging effects. Hinojosa Laborde et al.
[82] addressed this question by following MAP by telemetry for a year in DS rats maintained on a LS diet. This study found that ovariectomy at a young age accelerated the age-associated increase in MAP whereas $E_{2}$ replacement in the ovariectomized rats markedly attenuated this effect. The fact that MAP was significantly lower in the $E_{2}$ replaced group compared to the intact group after one year suggests $E_{2}$ treatment can protect against the ageassociated increase in MAP [82]. At 1 year of age, plasma $E_{2}$ in the ovariectomized DS rats treated chronically with $\mathrm{E}_{2}$ was $33 \%<$ levels found in young 4 mo DS rats [82]. Therefore, it would be informative to modify the $E_{2}$ replacement regimen in the ovariectomized rats so that similar $E_{2}$ levels to the young rats were achieved even after 1 year and then determine if these higher plasma $\mathrm{E}_{2}$ levels further improved upon or even totally prevented the age-associated increase in MAP. Mimicking the cycling of $E_{2}$ that is found in the young intact female is another important variable that needs to be investigated. A constant replacement dose of $E_{2}$ might desensitize ERs in a manner similar to how super agonists of the leutinizing hormone (LH) receptor cause receptor down regulation [117]. Thus, it is possible that mimicking the estrus cycle would result in greater attenuation of the age-associated increase in arterial pressure by preventing chronic ER desensitization.

Far less is known regarding the effects of progesterone loss on blood pressure since few studies have investigated the role of ovarian hormones other than $E_{2}$. In 1997, Crofton et al. [115] found that progesterone had no effect in and of itself on SBP in ovariectomized rats in the DOCA- $\mathrm{NaCl}$ model; however, this study did find that progesterone slowed the ability of $\mathrm{E}_{2}$ treatment to attenuate the blood pressure raising effects of ovariectomy. Studies are clearly needed to investigate the role of progesterone in diverse experimental models of hypertension to fully understand the role of progestins in blood pressure control. This is particularly relevant to women on hormone replacement regimens. In fact, clinical studies have shown that some progestins impair endothelial function in women while others do not, suggesting that certain progestins like depot-medroxyprogesterone acetate can inhibit the beneficial effects of $E_{2}$ while others like drospirenone are without effect [118-120].

Ten years ago, studies of estrogen receptor alpha and beta $(E R \alpha$ \& ER $\beta)$ null mice suggested that ER $\beta$ protects against the age-associated increase in arterial pressure since at 6-7 months of age compared to wild type (WT), SBP was shown to be elevated by 17 and $28 \mathrm{~mm} \mathrm{Hg}$ in the female and male KO mice, respectively [121]. In contrast, the ER $\alpha$ null mouse did not show a similar age-associated increase in SBP. Pharmacological studies using ER subtype selective ligands in the SHR revealed that ligand-dependent activation of ER $\beta$ lowers arterial pressure to a greater 

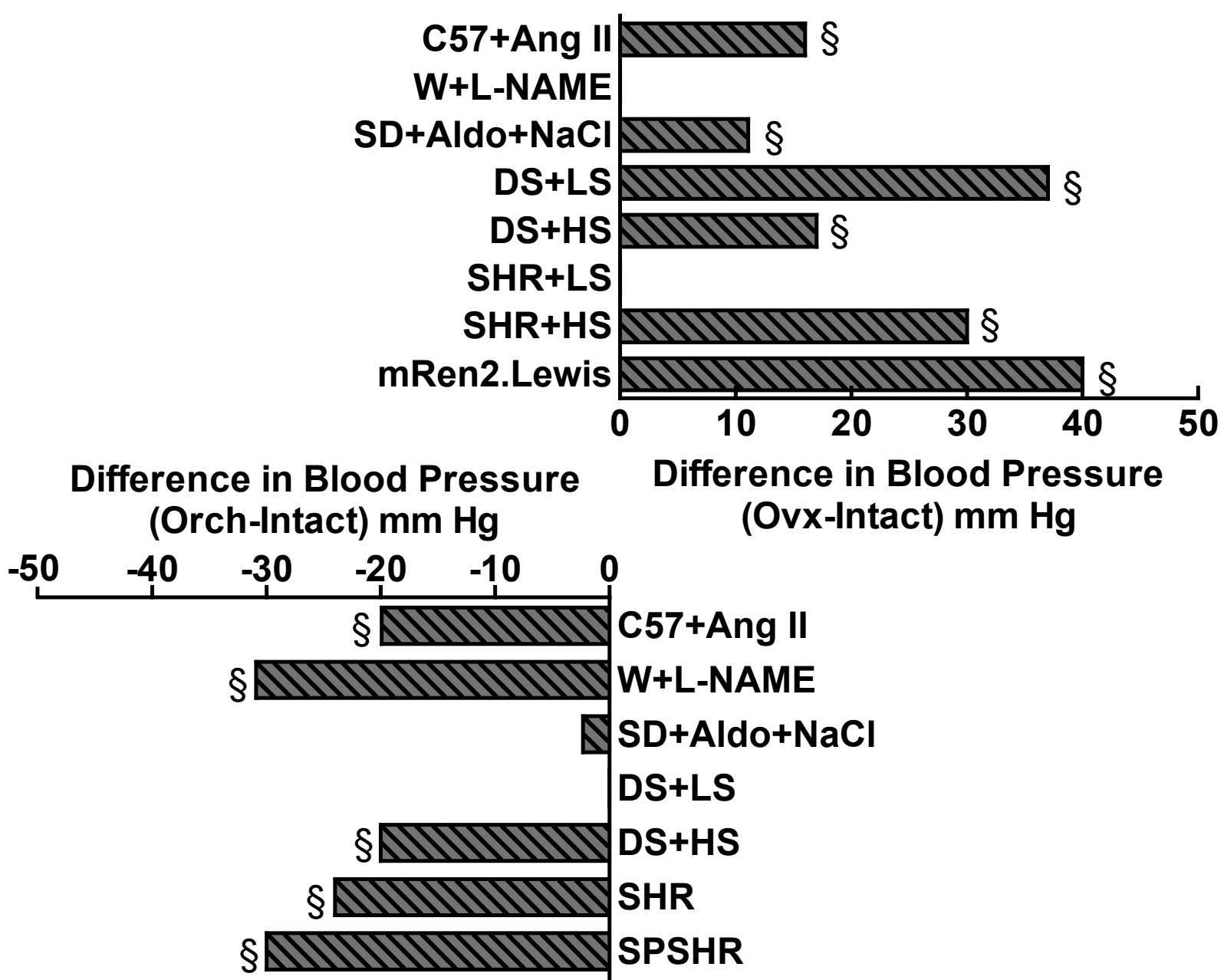

Figure 11 Effect of gonadectomy on blood pressure in experimental models of hypertension. Top panel, Shown is the difference in blood pressure between ovariectomized (Ovx) and intact (Intact) females in animal models of hypertension including Ang II infusion in C57 mice (C57 +Ang II) [38] $]^{a}$, Wistar rats infused with L-NAME (W+L-NAME) [44] , SD rats treated with deocycorticosterone acetate and HS (SD+DOCA+NaCl) [54] $]^{\mathrm{a}}$, DS rats [57] ${ }^{\mathrm{a}}$ and the SHR [112] ${ }^{\mathrm{a}}$ maintained on a LS and HS diet and the mRen2.Lewis rat [111] $]^{c}$. Bottom panel, Shown is the difference in blood pressure between orchiectomy (Orch) and intact (Intact) males in animal models of hypertension including C57+Ang II [38] $]^{\mathrm{a}}$, W+L-NAME [44] $]^{\mathrm{c}}$, SD+DOCA+NaCl [54] ${ }^{\mathrm{a}}$, DS maintained on a LS and HS diet [173] $]^{\mathrm{a}}$, SHR [146] ${ }^{\mathrm{b}}$ and the SPSHR [145] $]^{\mathrm{c}}$. §p < 0.05 vs Intact, same sex (see cited references for experimental and statistical details of individual studies). Note, studies measuring MAP by radiotelemetry ${ }^{\mathrm{a}}$ were preferentially cited over studies using indwelling catheters ${ }^{b}$ or those reporting SBP determined by tail plethysmographyc

extent than $E_{2}$ alone or the $E R \alpha$ agonist [122]; however, these studies were conducted solely in the female so this study did not assess if sex differences in the activity of these receptors contributes to sex differences in arterial pressure.

The gonadal hormone milieu changes markedly throughout the life of a woman. After puberty, $E_{2}$ levels markedly increase by $5-10$-fold [123,124]. Five years or more after menopause, $E_{2}$ levels drop by greater than 10fold compared to levels in normal cycling women [124]. The vast majority of research in menopause [125] has centered on the role of the precipitous drop in $E_{2}$ secretion from the ovarian follicles that occurs at this life transition [126]; however, other significant hormonal changes are also occurring. By the onset of menopause, $\mathrm{T}$ declines by approximately $40 \%$ [124]. The fact that the decline in $\mathrm{T}$ is far less dramatic than the drop in $\mathrm{E}_{2}$ means that the $\mathrm{T}: \mathrm{E}_{2}$ ratio markedly increases as a woman transitions into menopause.

As women approach menopause, atresia of the ovarian follicles occurs, fertility declines and serum follicle stimulating hormone (FSH) and LH start to surge in an effort to produce more ovarian follicles [126]. After menopause, there is more than a 10-fold increase in the levels of FSH and $\mathrm{LH}$, the pituitary hormones of the hypothalamic-pituitary-ovarian axis, that are secreted in response to the hypothalamic hormone, gonadotropin releasing hormone [124]. The secretion of these hormones is tightly regulated 
through hypothalamic-pituitary-ovarian feedback mechanisms. Supplementation with $\mathrm{E}_{2}$ markedly reduces FSH and LH levels in postmenopausal women, although levels remain significantly higher than those found in premenopausal women [126]. Studies investigating the role of $E_{2}$ in the age-associated increases in arterial pressure are confounded by changes in these hormones of the hypothalamic-pituitary-ovarian axis and therefore, the effects of $E_{2}$ deficiency can not be separated from the effects of rising FSH and LH levels.

Some studies suggest that elevation of FSH contributes to hypertension-associated disease. Chu et al. [127] showed that elevated FSH in premenopausal cycling women is associated with increased cardiovascular risk. The authors studied 40 women between the ages of 29 to 49 with normal menstrual cycles and premenopausal levels of $E_{2}$ who were not receiving exogenous hormone or statin treatment. Total cholesterol and low density lipoprotein were significantly higher in women who had an FSH level $\geq 7$ IU/I compared to those with an FSH $\leq$ $7 \mathrm{IU} / \mathrm{I}$ and these effects were independent of age. Patients with low FSH had $\mathrm{E}_{2}$ levels around $27 \mathrm{pg} / \mathrm{ml}$ whereas patients with high FSH had $\mathrm{E}_{2}$ levels around $52 \mathrm{pg} / \mathrm{ml}$. If the increased prevalence of cardiovascular risk factors is solely due to lower $E_{2}$ levels then the opposite findings would be expected, namely, that the premenopausal women with higher plasma $\mathrm{E}_{2}$ levels would have less cardiovascular risk factors than those women with lower plasma $\mathrm{E}_{2}$ levels. This study implicates a role for FSH and $\mathrm{LH}$ in and of themselves in cardiovascular risk.

Inactivating mutations in the FSH receptor gene have been reported to cause hereditary hypergonadotropic ovarian failure in women [128]. More recently, Nakayama et al. [129] examined 5 single nucleotide polymorphisms in the FSH receptor gene in more than 1000 essential hypertension patients and age-matched controls in a subgroup analysis of the Hypertensive Section of the Japanese Millennium Project. One single nucleotide polymorphism in the 5'-untranslated region of the FSH receptor gene occurred with increased frequency in women with hypertension. Patients with the A/A genotype in this polymorphism exhibited lower levels of FSH receptor transcriptional activity and had lower $E_{2}$ levels than those without the A/A genotype (G/G or G/A). These studies suggest that this single nucleotide polymorphism is a susceptibility mutation for essential hypertension in women and underscores the value of future studies that focus on ovarian hormone changes in addition to $E_{2}$ in blood pressure control. Surprisingly, the roles of T, LH and FSH and changes in their ratio to $\mathrm{E}_{2}$ (e.g., $\mathrm{T}: \mathrm{E}_{2}, \mathrm{LH}: \mathrm{E}_{2}$ \& $\mathrm{FSH}: \mathrm{E}_{2}$ ) throughout a woman's life span are generally neglected in hypertension research and consequently, much less is known regarding their specific effects on blood pressure control.

\section{Testes and testosterone}

There are fewer studies investigating the influence of the testicular hormonal milieu on blood pressure compared to studies of the ovarian hormonal milieu. As in women, as men age, the prevalence of hypertension increases (Figures 1 \&2). Accompanying this rise in arterial pressure is a gradual decrease in total $\mathrm{T}$. By the time men reach the eighth decade, free $\mathrm{T}$ drops to approximately $50 \%$ of the lifetime maximum [130-133]. This gradual decrease in $\mathrm{T}$ is misleading since bioavailable $\mathrm{T}$ constitutes only a small fraction (1-3\%) of serum $\mathrm{T}$ since the majority of this circulating steroid is bound to sex-hormone binding globulin $[134,135]$. Since sex-hormone binding globulin levels increase nearly 2 -fold over the male lifespan, bioavailable $\mathrm{T}$ is markedly decreased by aging [136,137]. A positive correlation among aging, arterial pressure and decreasing bioavailable $\mathrm{T}$ exists and hypertensive men have lower $\mathrm{T}$ [138-140] and androstenedione [140] than normotensive men. This inverse relationship between $\mathrm{T}$ and arterial pressure [141] suggests that hypertension in aging men is associated with decreased $\mathrm{T}$ activity.

While it is difficult to isolate the effects of declining $\mathrm{T}$ levels on blood pressure from other effects of advancing age on hypertension-associated disease [142], studies of oncology patients support the idea that $\mathrm{T}$ deficiency increases blood pressure in men. Surgical removal of the testes due to testicular cancer results in higher arterial pressures than that found in age-matched controls [143]. Furthermore, there was an inverse association between $\mathrm{T}$ levels and arterial pressure in these cancer survivors. Thus, these studies suggest that $\mathrm{T}$ deficiency has an adverse effect on arterial pressure. A study of 22 prostate cancer patients found that central arterial pressure was increased after $\mathrm{T}$ deficiency was induced by 3 mo treatment with LH-releasing hormone agonists [144]. Since T is converted to $E_{2}$, lower levels of $T$ in men are also associated with lower levels of $E_{2}$. LH receptor agonists not only reduced $\mathrm{T}$ from 14.5 to $1.2 \mathrm{nmol} /$ liter, $\mathrm{E}_{2}$ was reduced by 3 -fold [144]. Thus, it remains unclear as to whether the increased arterial pressure in these men was due to the loss of $\mathrm{T}$, decreased $\mathrm{E}_{2}$ or changes in the $\mathrm{T}: \mathrm{E}_{2}$ ratio.

In contrast to the clinical data suggesting that $\mathrm{T}$ deficiency exacerbates hypertension, $\mathrm{T}$ deficiency induced by orchiectomy lowers blood pressure in several experimental models of hypertension including Ang II infusion [38], DOCA-salt [54], chronic L-NAME treatment [44] and in the SPSHR [145] and SHR on either a normal salt and HS diet [146]. Orchiectomy also reduced MAP by 33 $\mathrm{mm} \mathrm{Hg}$ in the $\alpha 1$ soluble guanylate cyclase $\mathrm{KO}$ mouse [75]. In contrast, orchiectomy had no effect on DS rats maintained on a LS diet although on a HS diet, removing the testes reduced arterial pressure in these animals [116] (Figure 11). What makes the DS-LS model different from 
these above models is that the DS-LS rats were normotensive. Thus, it is worth exploring whether or not testicular hormones only affect blood pressure in hypertensive models. Investigators have compared intact with orchiectomized animals treated with and without $\mathrm{T}$. Treatment with $\mathrm{T}$ prevented the arterial pressure lowering effects of orchiectomy in the DOCA- $\mathrm{NaCl}$ [115] infused model as well as in the SHR [69,146-148], suggesting that T deficiency due to the gonadectomy lowers arterial pressure in these models of hypertension.

The absence of the androgen receptor (AR) did not affect arterial pressure under basal conditions as no differences in MAP were found between male WT and AR null mice (ARKO) nor was there any effect of AR deficiency on the magnitude of Ang II-induced hypertension [149]. This study suggests the AR is not a major factor in the control of arterial blood pressure. In contrast to conclusions drawn from comparing male ARKO and WT mice, the AR antagonist flutamide reduced blood pressure in the male SHR $[145,150]$ and the male SPSHR [145]. Flutamide also attenuated the development of hypertension in male TGR(mRen2)27 rats [151] and the male $\alpha 1$ soluble guanylate cyclase $\mathrm{KO}$ mouse [75]. These studies with flutamide indicate that inhibiting the AR lowers arterial pressure suggesting that the AR contributes to hypertension. To address the discrepancy between the ARKO mouse data and the flutamide data, experiments are needed to ensure flutamide is acting solely through the AR and that no pharmacological differences exist in the Emax or $\mathrm{EC}_{50}$ in the Ang II-blood pressure dose response curve between WT and ARKO mice.

The cytochrome P450 enzyme aromatase produces $E_{2}$ and mice with a targeted disruption of the aromatase gene are deficient in $E_{2}$. No detectable differences in SBP were reported between the aromatase $\mathrm{KO}$ and WT female mice [152]. The finding that a deficiency in $E_{2}$ induced by aromatase disruption had no detectable effect on SBP is consistent with studies in WT mice that showed $E_{2}$ depletion by ovariectomy did not alter basal arterial pressure $[38,39]$ and experiments in female rats that showed aromatase inhibition did not alter basal arterial pressure [153]. The aromatase KO did however exhibit a lower basal DBP than the WT and this was ascribed to greater BP variability within mid and high frequency bands and loss of autonomic control of the heart. Although the authors did not induce hypertension in the aromatase $\mathrm{KO}$ mice, one might predict that the $\mathrm{KO}$ females would have a higher magnitude of Ang II-dependent hypertension than their WT littermates since ovariectomized mice have a higher degree of Ang II-dependent hypertension than the intact females $[38,39]$. These are important experiments to conduct since previous studies with the aromatase inhibitor 10-propargyl-androst-4-ene,3,17-dione (19-AA) showed that 19-AA attenuated arterial pressure in an inbred salt-sensitive rat strain [154] and the SHR [155]; however, 19-AA also inhibits non-aromatizing adrenal 19-hydroxylation - a key step in forming 19-nordeoxycorticosterone, so it was unclear whether or not the attenuation of BP was due to $E_{2}$ deficiency or lowering of 10-nor-corticosteroids in these experiments.

Why then does this majority of the animal data directly conflict with the clinical data showing $\mathrm{T}$ deficiency is associated with blood pressure elevation? One explanation is the discrepancy in age. Animal castrations for the most part were performed on young animals while the clinical findings are primarily reported on men in their fifth to seventh decades of life. In fact, when orchiectomies in the SHR were conducted at 6 mo of age [145], there was no effect of the gonadectomy on SBP whereas when castration was performed between 3 weeks to 4 months [69,146-148], orchiectomy markedly attenuated the magnitude and slowed the rate of the developing hypertension. Taken together, these clinical and experimental studies suggest that $\mathrm{T}$ has bimodal effects. At high levels such as found at early ages, $\mathrm{T}$ adversely contributes to mechanisms of hypertension, while at later ages when $T$ levels naturally decline, there is insufficient $\mathrm{T}$ protection. Perhaps $\mathrm{T}$ action follows a physiological Ushaped response in which doses that are too low or too high are equally disadvantageous to the animal.

Studies of $\mathrm{T}$ and blood pressure have also been investigated in the female. In women with excess $\mathrm{T}$ production, $\mathrm{T}$ has a blood pressure elevating effect. Women with polycystic ovary syndrome have elevated $\mathrm{T}$ levels and there is a positive association between $\mathrm{T}$ levels and arterial pressure [156]. This latter observation emphasizes that $\mathrm{T}$ dosage or ratio to other hormones (e.g., $\mathrm{T}: \mathrm{E}_{2}$ ) may impact blood pressure. Clearly more research into of $\mathrm{T}$ action is needed to sort out the role of $\mathrm{T}, \mathrm{E}_{2}$ and the ratio of $\mathrm{T}: \mathrm{E}_{2}$ in blood pressure control in both the male and female.

\section{Effect of the sex chromosomes on blood pressure}

Although gonadal sex is a major difference between men and women, it is not the only difference. The sex chromosome complement is also distinct. Men have one X and one $\mathrm{Y}$ chromosome whereas women have two $\mathrm{X}$ and no $\mathrm{Y}$ chromosomes. Thus, the sex chromosome gene dosage is different between the sexes. Men express $\mathrm{Y}$ chromosome genes that women do not. Moreover, the second X chromosome is inactivated in each cell in the woman's body, but this inactivation is not complete and $15-17 \%$ of genes on the inactivated X chromosome (approximately 200-300 genes) escape X-inactivation [157]. Therefore, the physiology of blood pressure control could be differentially affected by sexual dimorphism in the expression of these X-linked genes. Furthermore, 
men only express the $\mathrm{X}$ from their mother $\left(\mathrm{X}^{\mathrm{m}}\right)$ while women express $50 \%$ of their $\mathrm{X}$ genes from their father $\left(\mathrm{X}^{\mathrm{p}}\right)$ and $50 \%$ from their mother $\left(\mathrm{X}^{\mathrm{m}}\right)$. Thus, men and women possess distinct differences in parental imprinting of the $\mathrm{X}$ chromosome which can have a profound effect on physiology and pathophysiology [158].

There are many men walking around with more than one Y chromosome, only they don't know it because it is rarely associated with a phenotype except perhaps that of being taller than usual. These XYY men have normal blood pressure, suggesting $Y$ gene dosage does not adversely affect blood pressure [159]. In contrast, women with XO Turner syndrome exhibit a higher incidence of hypertension than age-matched women with premature ovarian failure (46, XX) [160]. Thus, the loss of the second $\mathrm{X}$ negatively impacts arterial pressure, suggesting loss of gene expression from the second $\mathrm{X}$ has significant consequences for normal blood pressure control. A study comparing the lipid profile in $\mathrm{X}^{\mathrm{m}} \mathrm{O}$ versus $\mathrm{X}^{\mathrm{p}} \mathrm{O}$ Turner women suggests maternal imprinting of the $\mathrm{X}$ chromosome adversely affects the lipid profile compared to paternal imprinting [161]. Triglycerides, low density lipoprotein, cholesterol and visceral body fat content were all higher in $\mathrm{X}^{\mathrm{m}} \mathrm{O}$ compared to $\mathrm{X}^{\mathrm{P}} \mathrm{O}$. While blood pressure was not investigated in this study, the association between hypertension and adverse lipid profiles, suggests parental imprinting impacts blood pressure control as well.

Studies in the four core genotype mouse model are well suited for investigating mechanisms between the sexes since sex chromosome effects can be distinguished from gonadal sex effects (Figure 12). In this model, the Sry gene was deleted from the $\mathrm{Y}$ chromosome through a natural mutation $\left(\mathrm{Y}^{-}\right)$[162]. Thus, the $\mathrm{XY}^{-}$mouse does not develop testes, but instead, develops ovaries and

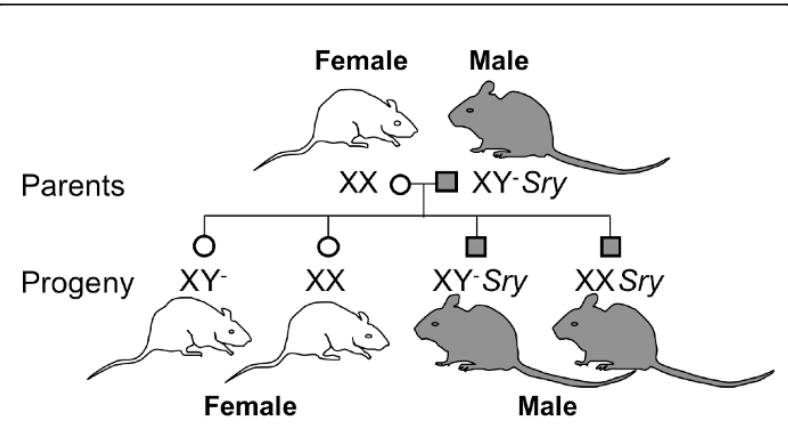

Figure 12 Generation of the four core genotype. The Sry gene was spontaneously deleted from the $Y$ chromosome $\left(Y^{-}\right)$and transferred to an autosome resulting in the $X Y^{-}$Sry male mouse. Breeding XX females with $X Y$ Sry males produces the four core genotype: $X Y^{-}$and $X X$ females and $X Y^{-}$Sry and $X X$ Sry males. We refer to $X X$ and $X Y$ as $X X$ and $X Y$-Females and $X X$ Sry and $X Y$ Sry as $X X-$ and $X Y$-Males throughout the text. expresses a female gonadal hormone phenotype. The Sry gene was also inserted onto an autosome, creating $\mathrm{XY}^{-}$ Sry and XXSry transgenic mice that regardless of the sex chromosome complement (XY vs. XX) are gonadal males (see review by Arnold [163]).

We have used the four core genotype mouse model to isolate sex chromosome effects from gonadal sex effects in the Ang II-induced model of hypertension. We found that the magnitude of the hypertension was greater in gonadectomized XX mice compared to gonadectomized $\mathrm{XY}$ mice regardless of whether the mice were born male or female [39] (Figure 13). This finding suggests that under conditions of gonadal hormone deficiency, a sex chromosome effect is either unmasked or expressed. We do not know at this point whether the sex chromosome effect on MAP is due to the XX or XY sex chromosome complement. If it is housed in the XX complement, then this finding may have negative implications for women with ovarian hormone deficiency such as women with premature ovarian failure or postmenopausal women. In this case, an adverse effect housed in the double X sex chromosomes could contribute to why the prevalence of hypertension is higher in these populations.

Caeiro, X.E. et al. [164] recently reported that C57BL/6 mice with the XY sex chromosomal complement show a lesser decrease in heart rate induced by Ang II when compared to the response in the XX sex chromosome complement. They also showed involvement of the sex chromosome complement in the baroreflex regulation of heart rate and that the sex chromosome effect contributes to the sex differences in the Ang II-bradycardic baroreflex response. These findings support our previous findings showing a sex chromosome effect on the magnitude of hypertension [39] and other studies suggesting certain brain functions are regulated by sex chromosome independently of the gonadal state [163].

Studies implicate a role for Sry in the SHR genetic model of hypertension. Switching the Y chromosome between SHR and the normotensive Wistar-Kyoto (WKY) rat increases arterial pressure by $15-30 \mathrm{~mm} \mathrm{Hg}$ in WKY and reduces the arterial pressure to a similar degree in SHR $[165,166]$. Furthermore, the SHR Y chromosome is associated with increased sympathetic nervous system activity. When the Sry1 gene was delivered to the WKY kidney, the renal sympathetic nervous system [167] was activated and arterial pressure increased in this normotensive strain. Thus, these studies suggest it is the Sry gene on the $\mathrm{Y}$ chromosome that is contributing to the hypertension in the SHR. These Sry findings in the SHR do not, however, explain the observation of a sex chromosome effect in the four core genotype mice since the magnitude of the hypertension was higher in the gonadectomized XX mice compared to the XY mice independently of whether they were born with testes $(+S r y)$ or ovaries $(-S r y)$ [39]. 


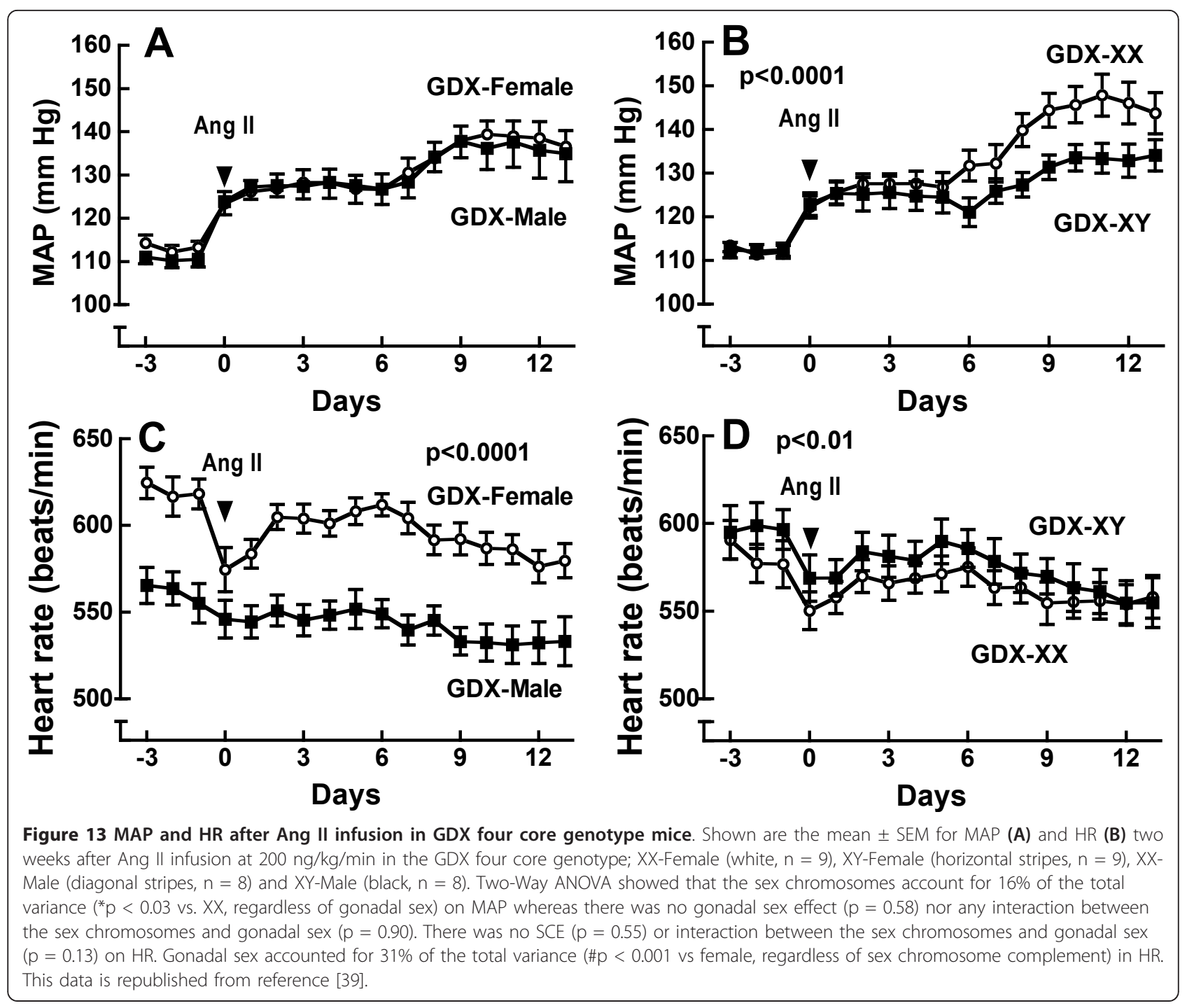

While many studies have investigated the role of gonadal hormones on physiological parameters that are known to modulate arterial pressure (e.g., endothelial function, renal function, and the sympathetic nervous system), it is imperative to realize that demonstrating hormonal regulation of one of these parameters in either sex does not mean this mechanism is a major contributor to male-female differences in blood pressure control. Thousands of genes [168] are differentially expressed in male and female tissues and not surprisingly, whole signaling networks are also differentially expressed [169]. A microarray analysis of 23,574 transcripts showed that thousands of genes are differentially expressed between male and female mice in a tissuespecific manner including in the brain, liver, adipose and muscle tissue and that sex differences exist in the quantitative trait loci that control subsets of these genes
[168]. While most of this differential gene expression can be attributed to sex differences in the adult gonadal hormone milieu, some differences were due to the sex chromosomes themselves [169]. Thus, comparisons of hormone effects in male and female animals are difficult to interpret given the magnitude of gene expression differences between the sexes. Furthermore, it behooves us to remember that blood pressure is a complex physiological trait that is controlled by whole networks of systems with no one gene acting in a vacuum. It is simply not valid to conclude the hormones are acting via the same mechanism in males and females just because a similar effect on blood pressure is observed in both sexes. Moreover, the underlying pathology, dose or combination of agents, age, and other factors are likely to determine whether the effects of gonadal steroids are beneficial or adverse. 


\section{Conclusions}

Sex differences in blood pressure and the prevalence of hypertension are highly conserved across race, ethnicity and country of origin. This robust finding in humans is also observed among animal species including mammals and avian species. While differences in the gonadal steroid profile contribute to the sexual dimorphism in blood pressure control, the sex chromosomes independently of the gonadal hormone milieu also contribute. Gaps in our knowledge regarding sex differences in primary hypertension include the role of T, FSH and $\mathrm{LH}$ and the changes in the ratios of these steroids in impacting blood pressure in both men and women across the life span.

Studies comparing male and female differences in a physiological parameter like blood pressure have numerous confounds whereas studies conducted using the four core genotype mouse model are uniquely able to isolate sex chromosome from gonadal hormone effects that occur in utero or during development. Alternatively, focusing on gonadal hormone regulation within one sex is a valuable strategy for gaining insights relevant to that specific sex. Moreover, focusing on genes on the Y chromosome that are not found on the $\mathrm{X}$ and the role of genes that escape $\mathrm{X}$-inactivation or studying the influence of parental imprinting and mosacisim on arterial pressure is likely to uncover new insights into blood pressure control that may ultimately be used to develop novel targets for the treatment of hypertension and associated disease as well as provide the rationale for treating men and women with antihypertensive regimens that reach maximal optimization in both sexes.

\section{Acknowledgements}

This work was supported by grants R01 AG019291 and R01 HL057502 to KS, and R21 AG037832 to HJ.

\section{Authors' contributions}

$\mathrm{KS}$ and $\mathrm{HJ}$ each contributed to the literature review and the writing of this manuscript. All authors read and approved the final manuscript.

\section{Authors' information}

KS is the director of Center for the Study of Sex Differences in health, aging and disease, and the vice-chair for Research in Department of Medicine at Georgetown University Medical Center.

\section{Competing interests}

The authors declare that they have no competing interests.

Received: 7 September 2010 Accepted: 14 March 2012

Published: 14 March 2012

\section{References}

1. Arnold AP, Itoh Y, Melamed E: A bird's-eye view of sex chromosome dosage compensation. Annu Rev Genomics Hum Genet 2008, 9:109-127.

2. Jones DW, Hall JE: Seventh report of the Joint National Committee on Prevention, Detection, Evaluation, and Treatment of High Blood Pressure and evidence from new hypertension trials. Hypertension 2004, 43:1-3.

3. Waeber B, de la Sierra A, Ruilope LM: Target organ damage: how to detect it and how to treat it? J Hypertens Suppl 2009, 27:S13-18.
4. Saini M, Shuaib A: Blood pressure lowering and stroke. Expert Rev Neurother 2010, 10:225-241.

5. Veglio F, Paglieri C, Rabbia F, Bisbocci D, Bergui M, Cerrato P: Hypertension and cerebrovascular damage. Atherosclerosis 2009, 205:331-341.

6. Pula $\mathrm{JH}$, Eggenberger E: Posterior reversible encephalopathy syndrome. Curr Opin Ophthalmol 2008, 19:479-484.

7. Bartynski WS: Posterior reversible encephalopathy syndrome, part 2 controversies surrounding pathophysiology of vasogenic edema. AJNR Am J Neuroradiol 2008, 29:1043-1049.

8. DellaCroce JT, Vitale AT: Hypertension and the eye. Curr Opin Ophthalmol 2008, 19:493-498.

9. Firdaus M, Sivaram CA, Reynolds DW: Prevention of cardiovascular events by treating hypertension in older adults: an evidence-based approach. $J$ Clin Hypertens (Greenwich) 2008, 10:219-225.

10. Zhou L, Deng W, Fang P, He D, Zhang W, Liu K, Hu R: Prevalence, incidence and risk factors of chronic heart failure in the type 2 diabetic population: systematic review. Curr Diabetes Rev 2009, 5:171-184.

11. Bakris GL, Ritz E: The message for World Kidney Day 2009: hypertension and kidney disease: a marriage that should be prevented. J Am SoC Hypertens 2009, 3:80-83.

12. Herrington WG, Mason PD: Slowing the progression of chronic kidney disease. Br J Hosp Med (Lond) 2009, 70:634-638.

13. Grossman E, Messerli FH: Hypertension and diabetes. Adv Cardiol 2008, 45:82-106

14. Kearney PM, Whelton M, Reynolds K, Muntner P, Whelton PK, He J: Global burden of hypertension: analysis of worldwide data. Lancet 2005, 365:217-223.

15. Egan $B M$, Zhao $Y, A x o n$ RN: US trends in prevalence, awareness, treatment, and control of hypertension, 1988-2008. JAMA 2010, 303:2043-2050.

16. Law MR, Morris JK, Wald NJ: Use of blood pressure lowering drugs in the prevention of cardiovascular disease: meta-analysis of 147 randomised trials in the context of expectations from prospective epidemiological studies. BMJ 2009, 338:b1665.

17. Murphy BP, Stanton T, Dunn FG: Hypertension and myocardial ischemia. Med Clin North Am 2009, 93:681-695.

18. Weinberger MH, Miller JZ, Luft FC, Grim CE, Fineberg NS: Definitions and characteristics of sodium sensitivity and blood pressure resistance. Hypertension 1986, 8:II127-134.

19. Boynton RE, Todd RL: Blood pressure readings of 75,258 university students. Arch Med Interna 1947, 80:454-462.

20. Roberts J: Blood pressure levels of persons 6-74 years. Book Blood pressure levels of persons 6-74 years (Editor ed.^eds.),Data from the National Health Survey edition. City

21. Stamler J, Stamler R, Riedlinger WF, Algera G, Roberts RH: Hypertension screening of 1 million Americans. Community Hypertension Evaluation Clinic (CHEC) program, 1973 through 1975. JAMA 1976, 235:2299-2306.

22. Calabrese A: New CDC Data Show Hispanics Outlive Other Americans. Book New CDC Data Show Hispanics Outlive Other Americans (Editor ed. ^eds.). City 2010

23. Flegal $\mathrm{KM}$, Carroll MD, Ogden $\mathrm{CL}$, Johnson $\mathrm{CL}$ : Prevalence and trends in obesity among US adults, 1999-2000. JAMA 2002, 288:1723-1727.

24. Cutler JA, Sorlie PD, Wolz M, Thom T, Fields LE, Roccella EJ: Trends in hypertension prevalence, awareness, treatment, and control rates in United States adults between 1988-1994 and 1999-2004. Hypertension 2008, 52:818-827.

25. Cornoni-Huntley J, LaCroix AZ, Havlik RJ: Race and sex differentials in the impact of hypertension in the United States. The National Health and Nutrition Examination Survey I Epidemiologic Follow-up Study. Arch Intern Med 1989, 149:780-788.

26. Rowland M, Roberts J: Blood pressure levels and hypertension in persons aged 6-74 years: United States, 1976089. NCHS Advance Data from Vital and Health Statistics of the National Center of Health Statistics 84. Book Blood pressure levels and hypertension in persons aged 6-74 years: United States, 1976089. NCHS Advance Data from Vital and Health Statistics of the National Center of Health Statistics 84. (Editor ed.^eds.) City: USA Government Publication; 1982.

27. Burt VL, Whelton P, Roccella EJ, Brown C, Cutler JA, Higgins M, Horan MJ, Labarthe D: Prevalence of hypertension in the US adult population. Results from the Third National Health and Nutrition Examination Survey, 1988-1991.[comment]. Hypertension 1995, 25:305-313. 
28. Vokonas PS, Kannel WB, Cupples LA: Epidemiology and risk of hypertension in the elderly: the Framingham Study. J Hypertens Suppl 1988, 6:S3-9.

29. Yong $L C$, Kuller $L H$, Rutan G, Bunker C: Longitudinal study of blood pressure: changes and determinants from adolescence to middle age. The Dormont High School follow-up study, 1957-1963 to 1989-1990. Am J Epidemiol 1993, 138:973-983.

30. Pencina MJ, D'Agostino RB, Larson MG, Massaro JM, Vasan RS: Predicting the 30-year risk of cardiovascular disease: the framingham heart study. Circulation 2009, 119:3078-3084

31. Blood pressure studies in 14 communities. A two-stage screen for hypertension. JAMA 1977, 237:2385-2391.

32. Klungel $\mathrm{OH}$, de Boer $\mathrm{A}$, Paes $\mathrm{AH}$, Seidell JC, Bakker $\mathrm{A}$ : Sex differences in the pharmacological treatment of hypertension: a review of populationbased studies. J Hypertens 1997, 15:591-600

33. Van Liere EJ, Stickney JC, Marsh DF: Sex Differences in Blood Pressure of Dogs. Science 1949, 109:489.

34. Ruiz-Feria CA, Zhang D, Nishimura H: Age- and sex-dependent changes in pulse pressure in fowl aorta. Comp Biochem Physiol A Mol Integr Physiol 2004, 137:311-320.

35. Dickinson CJ, Lawrence JR: A slowly developing pressor response to small concentrations of angiotensin. Its bearing on the pathogenesis of chronic renal hypertension. Lancet 1963, 1:1354-1356.

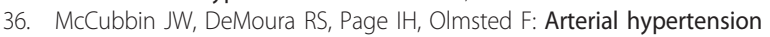
elicited by subpressor amounts of angiotensin. Science 1965 149:1394-1395.

37. Kawada N: BP and renal hemodynamics in a mouse model of Ang II slow pressor response. J Am Soc Nephrol 2001, 12:A2410.

38. Xue B, Pamidimukkala J, Hay M: Sex differences in the development of angiotensin II-induced hypertension in conscious mice. Am J Physiol Heart Circ Physiol 2005, 288:H2177-2184.

39. Ji H, Zheng W, Wu X, Liu J, Ecelbarger CM, Watkins R, Arnold AP, Sandberg K: Sex chromosome effects unmasked in angiotensin IIinduced hypertension. Hypertension 2010, 55:1275-1282.

40. Tatchum-Talom R, Eyster KM, Martin DS: Sexual dimorphism in angiotensin Il-induced hypertension and vascular alterations. Can $J$ Physiol Pharmacol 2005, 83:413-422.

41. Shi M, Khan O, Hu X, Maric C, Sandberg K, Verbalis JG, Ecelbarger CA, Roesch D: Sex differences in aldosterone-induced hypertension, electrolyte transporter abundances and renal pathology. 59th Annual Fall Conference and Scientific Sessions of the Council for High Blood Pressure Research in Association with the Council on the Kidney in Cardiovascular Disease; Washington, DC American Heart Association; 2005, 828.

42. Zatz R, Baylis C: Chronic nitric oxide inhibition model six years on Hypertension 1998, 32:958-964.

43. Baylis C, Mitruka B, Deng A: Chronic blockade of nitric oxide synthesis in the rat produces systemic hypertension and glomerular damage. J Clin Invest 1992, 90:278-281.

44. Sainz J, Osuna A, Wangensteen R, de Dios Luna J, Rodriguez-Gomez I, Duarte J, Moreno JM, Vargas F: Role of sex, gonadectomy and sex hormones in the development of nitric oxide inhibition-induced hypertension. Experimental physiology 2004, 89:155-162.

45. Ribeiro MO, Antunes E, de Nucci G, Lovisolo SM, Zatz R: Chronic inhibition of nitric oxide synthesis. A new model of arterial hypertension. Hypertension 1992, 20:298-303.

46. Navarro-Cid J, Maeso R, Rodrigo E, Munoz-Garcia R, Ruilope LM, Lahera V, Cachofeiro V: Renal and vascular consequences of the chronic nitric oxide synthase inhibition. Effects of antihypertensive drugs. Am J Hypertens 1996, 9:1077-1083.

47. Takase H, Moreau P, Kung CF, Nava E, Luscher TF: Antihypertensive therapy prevents endothelial dysfunction in chronic nitric oxide deficiency. Effect of verapamil and trandolapril. Hypertension 1996, 27:25-31.

48. Morton JJ, Beattie EC, Speirs A, Gulliver F: Persistent hypertension following inhibition of nitric oxide formation in the young Wistar rat: role of renin and vascular hypertrophy. J Hypertens 1993, 11:1083-1088.

49. Pendergrass KD, Pirro NT, Westwood BM, Ferrario CM, Brosnihan KB, Chappell MC: Sex differences in circulating and renal angiotensins of hypertensive mRen(2).Lewis but not normotensive Lewis rats. Am J Physiol Heart Circ Physiol 2008, 295:H10-20.
50. Rogers $J$, Mitchell AR, Maric C, Sandberg K, Myers A, Mulroney SE: Effect of sex hormones on renal estrogen and angiotensin type 1 receptors in female and male rats. American Journal of Physiology - Regulatory Integrative \& Comparative Physiology 2007, 292:R794-799.

51. Sullivan JC: Sex and the renin-angiotensin system: inequality between the sexes in response to RAS stimulation and inhibition. Am J Physiol Regul Integr Comp Physiol 2008, 294:R1220-1226.

52. Danser AH, Derkx FH, Schalekamp MA, Hense HW, Riegger GA, Schunkert $H$ : Determinants of interindividual variation of renin and prorenin concentrations: evidence for a sexual dimorphism of (pro)renin levels in humans. J Hypertens 1998, 16:853-862.

53. Mirza FS, Ong P, Collins P, Okamura K, Gerhard-Herman M, Williams GH, Seely EW: Effects of estradiol and the angiotensin II receptor blocker irbesartan on vascular function in postmenopausal women. Menopause 2008, 15:44-50

54. Xue B, Badaue-Passos D Jr, Guo F, Gomez-Sanchez CE, Hay M, Johnson AK Sex differences and central protective effect of 17beta-estradiol in the development of aldosterone/ $\mathrm{NaCl}$-induced hypertension. Am J Physiol Heart Circ Physiol 2009, 296:H1577-1585.

55. Ouchi Y, Share L, Crofton JT, litake K, Brooks DP: Sex difference in the development of deoxycorticosterone-salt hypertension in the rat. Hypertension 1987, 9:172-177.

56. Dahl L, Heine $M$, Tassinari $L$ : Role of genetic factors in susceptibility to experimental hypertension due to chronic excess salt ingestion. Nature 1962, 194:480-482

57. Hinojosa-Laborde C, Lange DL, Haywood JR: Role of female sex hormones in the development and reversal of dahl hypertension. Hypertension 2000, 35:484-489.

58. Ji H, Pesce C, Zheng W, Kim J, Zhang Y, Menini S, Haywood JR, Sandberg K Sex differences in renal injury and nitric oxide production in renal wrap hypertension. Am J Physiol Heart Circ Physiol 2005, 288:H43-47.

59. Sampson AK, Moritz KM, Jones ES, Flower RL, Widdop RE, Denton KM: Enhanced angiotensin II type 2 receptor mechanisms mediate decreases in arterial pressure attributable to chronic low-dose angiotensin II in female rats. Hypertension 2008, 52:666-671.

60. Yagil C, Hubner N, Kreutz R, Ganten D, Yagil Y: Congenic strains confirm the presence of salt-sensitivity QTLs on chromosome 1 in the Sabra rat model of hypertension. Physiol Genomics 2003, 12:85-95.

61. Wilson DK, Bayer L, Sica DA: Variability in salt sensitivity classifications in black male versus female adolescents. Hypertension 1996, 28:250-255.

62. Tamaya-Mori N, Uemura K, Iguchi A: Gender differences in the dietary lard-induced increase in blood pressure in rats. Hypertension 2002 39:1015-1020.

63. Galipeau D, Verma S, McNeill JH: Female rats are protected against fructose-induced changes in metabolism and blood pressure. Am $J$ Physiol Heart Circ Physiol 2002, 283:H2478-2484.

64. Alexander BT: Placental insufficiency leads to development of hypertension in growth-restricted offspring. Hypertension 2003, 41:457-462.

65. Franco Mdo C, Arruda RM, Dantas AP, Kawamoto EM, Fortes ZB, Scavone C, Carvalho MH, Tostes RC, Nigro D: Intrauterine undernutrition: expression and activity of the endothelial nitric oxide synthase in male and female adult offspring. Cardiovasc Res 2002, 56:145-153.

66. Okamoto K, Aoki K: Development of a strain of spontaneously hypertensive rats. Jpn Circ J 1963, 27:282-293.

67. Pinto YM, Paul M, Ganten D: Lessons from rat models of hypertension: from Goldblatt to genetic engineering. Cardiovasc Res 1998, 39:77-88.

68. Okamoto K, Hazama F, Yamori Y, Haebara H, Nagaoka A: Pathogenesis and prevention of stroke in spontaneously hypertensive rats. Clin Sci Mol Med Suppl 1975, 2:161s-163s.

69. Cambotti L, Cole FE, Gerall AA, Frohlich ED, MacPhee AA: Neonatal gonadal hormones and blood pressure in the spontaneously hypertensive rat. Am J Physiol 1984, 247:E258-264.

70. Graham D, Hamilton C, Beattie E, Spiers A, Dominiczak AF: Comparison of the effects of omapatrilat and irbesartan/hydrochlorothiazide on endothelial function and cardiac hypertrophy in the stroke-prone spontaneously hypertensive rat: sex differences. J Hypertens 2004, 22:329-337.

71. Mullins J, Peters J, Ganten D: Fulminant hypertension in transgenic rats harbouring the mouse Ren-2 gene. Nature 1990, 344:541-544. 
72. Chappell MC, Gallagher PE, Averill DB, Ferrario CM, Brosnihan KB: Estrogen or the AT1 antagonist olmesartan reverses the development of profound hypertension in the congenic mRen2.Lewis rat. Hypertension 2003, 42:781-786.

73. Trieu VN, Uckun FM: Male-associated hypertension in LDL-R deficient mice. Biochem Biophys Res Commun 1998, 247:277-279.

74. Yang T, Huang YG, Ye W, Hansen P, Schnermann JB, Briggs JP: Influence of genetic background and gender on hypertension and renal failure in COX-2-deficient mice. Am J Physiol Renal Physiol 2005, 288:F1125-1132.

75. Buys ES, Sips P, Vermeersch P, Raher MJ, Rogge E, Ichinose F, Dewerchin M, Bloch KD, Janssens S, Brouckaert P: Gender-specific hypertension and responsiveness to nitric oxide in sGCalpha1 knockout mice. Cardiovasc Res 2008, 79:179-186

76. Miller AA, Hislop AA, Vallance PJ, Haworth SG: Deletion of the eNOS gene has a greater impact on the pulmonary circulation of male than female mice. Am J Physiol Lung Cell Mol Physiol 2005, 289:L299-306.

77. John SW, Krege JH, Oliver PM, Hagaman JR, Hodgin JB, Pang SC, Flynn TG, Smithies O: Genetic decreases in atrial natriuretic peptide and saltsensitive hypertension. Science 1995, 267:679-681.

78. Lopez MJ, Wong SK, Kishimoto I, Dubois S, Mach V, Friesen J, Garbers DL, Beuve A: Salt-resistant hypertension in mice lacking the guanylyl cyclaseA receptor for atrial natriuretic peptide. Nature 1995, 378:65-68.

79. Hsu HH, Duning K, Meyer HH, Stolting M, Weide T, Kreusser S, van Le T, Gerard C, Telgmann R, Brand-Herrmann SM, et al: Hypertension in mice lacking the CXCR3 chemokine receptor. Am J Physiol Renal Physiol 2009, 296:F780-789.

80. Kotelevtsev $Y$, Brown RW, Fleming S, Kenyon C, Edwards CR, Seckl JR, Mullins JJ: Hypertension in mice lacking 11 beta-hydroxysteroid dehydrogenase type 2. J Clin Invest 1999, 103:683-689.

81. Printz MP: Radiotelemetry comes of age-perhaps just in time. Am J Physiol Regul Integr Comp Physiol 2004, 286:R818-819.

82. Hinojosa-Laborde C, Craig T, Zheng W, Ji H, Haywood JR, Sandberg K: Ovariectomy augments hypertension in aging female Dahl salt-sensitive rats. Hypertension 2004, 44:1-5.

83. Ferrari AU, Daffonchio A, Albergati F, Bertoli P, Mancia G: Intra-arterial pressure alterations during tail-cuff blood pressure measurements in normotensive and hypertensive rats. J Hypertens 1990, 8:909-911.

84. Brockway BP, Mills PA, Azar SH: A new method for continuous chronic measurement and recording of blood pressure, heart rate and activity in the rat via radio-telemetry. Clin Exp Hypertens A 1991, 13:885-895.

85. Irvine RJ, White J, Chan R: The influence of restraint on blood pressure in the rat. Journal of Pharmacological \& Toxicological Methods 1997, 38:157-162.

86. Tonkiss J, Trzcinska M, Galler JR, Ruiz-Opazo N, Herrera VL: Prenatal malnutrition-induced changes in blood pressure: dissociation of stress and nonstress responses using radiotelemetry. Hypertension 1998, 32:108-114.

87. Sullivan JC, Pollock JS, Pollock DM: Superoxide-dependent hypertension in male and female endothelin B receptor-deficient rats. Exp Biol Med (Maywood) 2006, 231:818-823.

88. Plehm R, Barbosa ME, Bader M: Animal models for hypertension/blood pressure recording. Methods Mol Med 2006, 129:115-126.

89. Kubota Y, Umegaki K, Kagota S, Tanaka N, Nakamura K, Kunitomo M, Shinozuka K: Evaluation of blood pressure measured by tail-cuff methods (without heating) in spontaneously hypertensive rats. Biol Pharm Bull 2006, 29:1756-1758.

90. Jee D, Moon HL: Gender may affect the hemodynamic response to induction and intubation in young adults. J Clin Anesth 2004, 16:563-567.

91. Dolan E, Stanton A, Atkins N, Den Hond E, Thijs L, McCormack P, Staessen J, O'Brien E: Determinants of white-coat hypertension. Blood Press Monit 2004, 9:307-309.

92. Abir-Khalil S, Zaimi S, Tazi MA, Bendahmane S, Bensaoud O, Benomar M: Prevalence and predictors of white-coat hypertension in a large database of ambulatory blood pressure monitoring. East Mediterr Health $J$ 2009, 15:400-407.

93. Hwang ES, Choi KJ, Kang DH, Nam GB, Jang JS, Jeong YH, Lee CH, Lee JY, Park HK, Park CH: Prevalence, predictive factor, and clinical significance of white-coat hypertension and masked hypertension in Korean hypertensive patients. Korean J Intern Med 2007, 22:256-262.

94. Fagard RH, Stolarz K, Kuznetsova T, Seidlerova J, Tikhonoff V, Grodzicki T, Nikitin Y, Filipovsky J, Peleska J, Casiglia E, et al: Sympathetic activity, assessed by power spectral analysis of heart rate variability, in whitecoat, masked and sustained hypertension versus true normotension. J Hypertens 2007, 25:2280-2285.

95. Weber MA, Neutel JM, Smith DH, Graettinger WF: Diagnosis of mild hypertension by ambulatory blood pressure monitoring. Circulation 1994, 90:2291-2298.

96. Neumann SA, Jennings JR, Muldoon MF, Manuck SB: White-coat hypertension and autonomic nervous system dysregulation. Am $J$ Hypertens 2005, 18:584-588.

97. Ogedegbe G, Pickering TG, Clemow L, Chaplin W, Spruill TM, Albanese GM, Eguchi K, Burg M, Gerin W: The misdiagnosis of hypertension: the role of patient anxiety. Arch Intern Med 2008, 168:2459-2465.

98. Tabeta I, Ueshiba H, Ichijo T, Hiroi N, Yakushiji F, Simojo M, Tsuboi K, Miyachi Y: Comment: the corticotropin-releasing hormone stimulation test in white coat hypertension. J Clin Endocrinol Metab 2002, 87:3672-3675.

99. Yagil C, Sapojnikov M, Kreutz R, Katni G, Lindpaintner K, Ganten D, Yagil Y: Salt susceptibility maps to chromosomes 1 and 17 with sex specificity in the Sabra rat model of hypertension. Hypertension 1998, 31:119-124.

100. Yagil C, Sapojnikov M, Kreutz R, Zurcher H, Ganten D, Yagil Y: Role of chromosome $\mathrm{X}$ in the Sabra rat model of salt-sensitive hypertension. Hypertension 1999, 33:261-265.

101. Mattson DL, Dwinell MR, Greene AS, Kwitek AE, Roman RJ, Jacob HJ, Cowley AW Jr: Chromosome substitution reveals the genetic basis of Dahl salt-sensitive hypertension and renal disease. Am J Physiol Renal Physiol 2008, 295:F837-842.

102. Staessen J, Bulpitt CJ, Fagard R, Lijnen P, Amery A: The influence of menopause on blood pressure. J Hum Hypertens 1989, 3:427-433.

103. Staessen JA, Ginocchio G, Thijs L, Fagard R: Conventional and ambulatory blood pressure and menopause in a prospective population study. $J$ Hum Hypertens 1997, 11:507-514.

104. Weiss NS: Premature menopause and aortoiliac occlusive disease. $J$ Chronic Dis 1972, 25:133-138.

105. Pal L, Santoro N: Premature ovarian failure (POF): discordance between somatic and reproductive aging. Ageing Res Rev 2002, 1:413-423.

106. Virdis R, Cantu MC, Ghizzoni L, Ammenti A, Nori G, Volta C, Cravidi C, Vanelli $M$, Balestrazzi $P$, Bernasconi $S$, et al: Blood pressure behaviour and control in Turner syndrome. Clin Exp Hypertens A 1986, 8:787-791.

107. Nathwani NC, Unwin R, Brook CG, Hindmarsh PC: Blood pressure and Turner syndrome. Clin Endocrinol (Oxf) 2000, 52:363-370.

108. Hjortland MC, McNamara PM, Kannel WB: Some atherogenic concomitants of menopause: The Framingham Study. Am J Epidemiol 1976, 103:304-311.

109. van Beresteyn EC, van $t$ Hof MA, De Waard H: Contributions of ovarian failure and aging to blood pressure in normotensive perimenopausal women: a mixed longitudinal study. Am J Epidemiol 1989, 129:947-955.

110. Matthews KA, Meilahn E, Kuller LH, Kelsey SF, Caggiula AW, Wing RR: Menopause and risk factors for coronary heart disease. The New England journal of medicine 1989, 321:641-646.

111. Chappell MC, Yamaleyeva LM, Westwood BM: Estrogen and salt sensitivity in the female mRen(2).Lewis rat. American journal of physiology 2006, 291: R1557-R1563.

112. Fang Z, Carlson SH, Chen YF, Oparil S, Wyss JM: Estrogen depletion induces $\mathrm{NaCl}$-sensitive hypertension in female spontaneously hypertensive rats. Am J Physiol Regul Integr Comp Physiol 2001, 281 R1934-1939.

113. Zheng W, Ji H, Maric C, Wu X, Sandberg K: Effect of dietary sodium on estrogen regulation of blood pressure in Dahl salt-sensitive rats. Am J Physiol Heart Circ Physiol 2008, 294:H1508-1513.

114. Xue B, Pamidimukkala J, Lubahn DB, Hay M: Estrogen receptor-alpha mediates estrogen protection from angiotensin II-induced hypertension in conscious female mice. Am J Physiol Heart Circ Physiol 2007, 292 H1770-1776.

115. Crofton JT, Share L: Gonadal hormones modulate deoxycorticosteronesalt hypertension in male and female rats. Hypertension 1997, 29:494-499.

116. Dahl LK, Knudsen KD, Ohanian EV, Muirhead M, Tuthill R: Role of the gonads in hypertension-prone rats. J Exp Med 1975, 142:748-759.

117. Hsueh AJ, Erickson GF: Extrapituitary action of gonadotropin-releasing hormone: direct inhibition ovarian steroidogenesis. Science 1979, 204:854-855.

118. Torgrimson BN, Meendering JR, Kaplan PF, Minson CT: Depotmedroxyprogesterone acetate and endothelial function before and after 
acute oral, vaginal, and transdermal estradiol treatment. Hypertension 2011, 57:819-824

119. Miner JA, Martini ER, Smith MM, Brunt VE, Kaplan PF, Halliwill JR, Minson CT: Short-term oral progesterone administration antagonizes the effect of transdermal estradiol on endothelium-dependent vasodilation in young healthy women. Am J Physiol Heart Circ Physiol 2011, 301:H1716-1722

120. Meendering JR, Torgrimson BN, Miller NP, Kaplan PF, Minson CT: A combined oral contraceptive containing $30 \mathrm{mcg}$ ethinyl estradiol and $3.0 \mathrm{mg}$ drospirenone does not impair endothelium-dependent vasodilation. Contraception 2010, 82:366-372.

121. Zhu Y, Bian Z, Lu P, Karas RH, Bao L, Cox D, Hodgin J, Shaul PW, Thoren P, Smithies $O$, et al: Abnormal vascular function and hypertension in mice deficient in estrogen receptor beta. Science 2002, 295:505-508.

122. Jazbutyte V, Arias-Loza PA, Hu K, Widder J, Govindaraj V, von Poser-Klein C, Bauersachs J, Fritzemeier KH, Hegele-Hartung C, Neyses L, et al: Liganddependent activation of ER\{beta\} lowers blood pressure and attenuates cardiac hypertrophy in ovariectomized spontaneously hypertensive rats. Cardiovasc Res 2008, 77:774-781.

123. Courant F, Aksglaede L, Antignac JP, Monteau F, Sorensen K, Andersson AM, Skakkebaek NE, Juul A, Bizec BL: Assessment of circulating sex steroid levels in prepubertal and pubertal boys and girls by a novel ultrasensitive gas chromatography-tandem mass spectrometry method. J Clin Endocrinol Metab 2010, 95:82-92.

124. Rothman MS, Carlson NE, Xu M, Wang C, Swerdloff R, Lee P, Goh VH, Ridgway EC, Wierman ME: Reexamination of testosterone, dihydrotestosterone, estradiol and estrone levels across the menstrual cycle and in postmenopausal women measured by liquid chromatography-tandem mass spectrometry. Steroids 2011, 76:177-182.

125. Reckelhoff JF: Sex steroids, cardiovascular disease, and hypertension: unanswered questions and some speculations. Hypertension 2005, 45:170-174.

126. Hall JE: Neuroendocrine changes with reproductive aging in women. Semin Reprod Med 2007, 25:344-351

127. Chu MC, Rath KM, Huie J, Taylor HS: Elevated basal FSH in normal cycling women is associated with unfavourable lipid levels and increased cardiovascular risk. Hum Reprod 2003, 18:1570-1573.

128. Aittomaki K, Lucena JL, Pakarinen P, Sistonen P, Tapanainen J, Gromoll J, Kaskikari $R$, Sankila EM, Lehvaslaiho $H$, Engel AR, et al: Mutation in the follicle-stimulating hormone receptor gene causes hereditary hypergonadotropic ovarian failure. Cell 1995, 82:959-968.

129. Nakayama T, Kuroi N, Sano M, Tabara Y, Katsuya T, Ogihara T, Makita Y, Hata A, Yamada M, Takahashi N, et al: Mutation of the follicle-stimulating hormone receptor gene $5^{\prime}$-untranslated region associated with female hypertension. Hypertension 2006, 48:512-518.

130. Kaufman JM, Vermeulen A: The decline of androgen levels in elderly men and its clinical and therapeutic implications. Endocr Rev 2005, 26:833-876.

131. Harman SM, Tsitouras PD: Reproductive hormones in aging men. I. Measurement of sex steroids, basal luteinizing hormone, and Leydig cell response to human chorionic gonadotropin. J Clin Endocrinol Metab 1980, 51:35-40.

132. Foresta C, Ruzza G, Mioni R, Guarneri G, Gribaldo R, Meneghello A, Mastrogiacomo I: Osteoporosis and decline of gonadal function in the elderly male. Horm Res 1984, 19:18-22.

133. Meier DE, Orwoll ES, Keenan EJ, Fagerstrom RM: Marked decline in trabecular bone mineral content in healthy men with age: lack of association with sex steroid levels. J Am Geriatr Soc 1987, 35:189-197.

134. van den Beld AW, de Jong FH, Grobbee DE, Pols HA, Lamberts SW: Measures of bioavailable serum testosterone and estradiol and their relationships with muscle strength, bone density, and body composition in elderly men. J Clin Endocrinol Metab 2000, 85:3276-3282.

135. Pardridge WM: Serum bioavailability of sex steroid hormones. Clin Endocrinol Metab 1986, 15:259-278.

136. Feldman HA, Longcope C, Derby CA, Johannes CB, Araujo AB, Coviello AD, Bremner WJ, McKinlay JB: Age trends in the level of serum testosterone and other hormones in middle-aged men: longitudinal results from the Massachusetts male aging study. J Clin Endocrinol Metab 2002, 87:589-598.

137. Deslypere JP, Young M, Wilson JD, McPhaul MJ: Testosterone and 5 alphadihydrotestosterone interact differently with the androgen receptor to enhance transcription of the MMTV-CAT reporter gene. Mol Cell Endocrinol 1992, 88:15-22.
138. Phillips GB, Jing TY, Resnick LM, Barbagallo M, Laragh JH, Sealey JE: Sex hormones and hemostatic risk factors for coronary heart disease in men with hypertension. J Hypertens 1993, 11:699-702.

139. Jaffe $A$, Chen $Y$, Kisch ES, Fischel B, Alon M, Stern N: Erectile dysfunction in hypertensive subjects. Assessment of potential determinants. Hypertension 1996, 28:859-862.

140. Hughes GS, Mathur RS, Margolius HS: Sex steroid hormones are altered in essential hypertension. J Hypertens 1989, 7:181-187.

141. Khaw KT, Barrett-Connor E: Blood pressure and endogenous testosterone in men: an inverse relationship. J Hypertens 1988, 6:329-332.

142. Kalin MF, Zumoff B: Sex hormones and coronary disease: a review of the clinical studies. Steroids 1990, 55:330-352.

143. Huddart RA, Norman A, Moynihan C, Horwich A, Parker C, Nicholls E, Dearnaley DP: Fertility, gonadal and sexual function in survivors of testicular cancer. Br J Cancer 2005, 93:200-207.

144. Smith JC, Bennett S, Evans LM, Kynaston HG, Parmar M, Mason MD, Cockcroft JR, Scanlon MF, Davies JS: The effects of induced hypogonadism on arterial stiffness, body composition, and metabolic parameters in males with prostate cancer. J Clin Endocrinol Metab 2001, 86:4261-4267.

145. Ganten U, Schroder G, Witt M, Zimmermann F, Ganten D, Stock G: Sexual dimorphism of blood pressure in spontaneously hypertensive rats: effects of anti-androgen treatment. J Hypertens 1989, 7:721-726.

146. Reckelhoff JF, Zhang H, Granger JP: Testosterone exacerbates hypertension and reduces pressure-natriuresis in male spontaneously hypertensive rats. Hypertension 1998, 31:435-439.

147. Chen YF, Meng QC: Sexual dimorphism of blood pressure in spontaneously hypertensive rats is androgen dependent. Life sciences 1991, 48:85-96.

148. Ely DL, Daneshvar H, Turner ME, Johnson ML, Salisbury RL: The hypertensive $\mathrm{Y}$ chromosome elevates blood pressure in F11 normotensive rats. Hypertension 1993, 21:1071-1075.

149. Ikeda $Y$, Aihara K, Sato T, Akaike M, Yoshizumi M, Suzaki $Y$, Izawa $Y$, Fujimura M, Hashizume S, Kato $M$, et al: Androgen receptor gene knockout male mice exhibit impaired cardiac growth and exacerbation of angiotensin Il-induced cardiac fibrosis. J Biol Chem 2005, 280:29661-29666.

150. Reckelhoff JF, Zhang H, Srivastava K, Granger JP: Gender differences in hypertension in spontaneously hypertensive rats: role of androgens and androgen receptor. Hypertension 1999, 34:920-923.

151. Baltatu O, Cayla C, Iliescu R, Andreev D, Jordan C, Bader M: Abolition of hypertension-induced end-organ damage by androgen receptor blockade in transgenic rats harboring the mouse ren-2 gene. J Am Soc Nephrol 2002, 13:2681-2687.

152. Head GA, Obeyesekere VR, Jones ME, Simpson ER, Krozowski ZS: Aromatase-deficient (ArKO) mice have reduced blood pressure and baroreflex sensitivity. Endocrinology 2004, 145:4286-4291.

153. Santmyire BR, Venkat V, Beinder E, Baylis C: Impact of the estrus cycle and reduction in estrogen levels with aromatase inhibition, on renal function and nitric oxide activity in female rats. Steroids 2010, 75:1011-1015.

154. Griffing GT, Melby JC, Holbrook M, Johnston ON: Antihypertensive effects of an aromatase inhibitor in inbred salt-sensitive rats. Hypertension 1991 17:771-775.

155. Melby JC, Holbrook M, Griffing GT, Johnston JO: Antihypertensive effects of an aromatase inhibitor in the spontaneously hypertensive rat. Hypertension 1987, 10:484-487.

156. Chen MJ, Yang WS, Yang JH, Chen CL, Ho HN, Yang YS: Relationship between androgen levels and blood pressure in young women with polycystic ovary syndrome. Hypertension 2007, 49:1442-1447.

157. Carrel L, Willard HF: X-inactivation profile reveals extensive variability in X-linked gene expression in females. Nature 2005, 434:400-404.

158. Davies W, Isles AR, Burgoyne PS, Wilkinson LS: X-linked imprinting: effects on brain and behaviour. Bioessays 2006, 28:35-44.

159. Ratcliffe SG, Read G, Pan H, Fear C, Lindenbaum R, Crossley J: Prenatal testosterone levels in XXY and XYY males. Horm Res 1994, 42:106-109.

160. Cooley M, Bakalov V, Bondy CA: Lipid profiles in women with $45, X$ vs 46 , XX primary ovarian failure. Jama 2003, 290:2127-2128.

161. Van PL, Bakalov VK, Zinn AR, Bondy CA: Maternal X chromosome, visceral adiposity, and lipid profile. JAMA 2006, 295:1373-1374. 
162. Lovell-Badge R, Robertson E: XY female mice resulting from a heritable mutation in the primary testis-determining gene, Tdy. Development (Cambridge, England) 1990, 109:635-646.

163. Arnold AP, Chen X: What does the "four core genotypes" mouse model tell us about sex differences in the brain and other tissues? Front Neuroendocrinol 2009, 30:1-9.

164. Caeiro XE, Mir FR, Vivas LM, Carrer HF, Cambiasso MJ: Sex chromosome complement contributes to sex differences in bradycardic baroreflex response. Hypertension 2011, 58:505-511.

165. Ely D, Caplea A, Dunphy G, Daneshvar H, Turner M, Milsted A, Takiyyudin M: Spontaneously hypertensive rat $\mathrm{Y}$ chromosome increases indexes of sympathetic nervous system activity. Hypertension 1997, 29:613-618.

166. Negrin CD, McBride MW, Carswell HV, Graham D, Carr FJ, Clark JS, Jeffs B, Anderson NH, Macrae IM, Dominiczak AF: Reciprocal consomic strains to evaluate y chromosome effects. Hypertension 2001, 37:391-397.

167. Ely D, Milsted A, Dunphy G, Boehme S, Dunmire J, Hart M, Toot J, Turner M: Delivery of sry1, but not sry2, to the kidney increases blood pressure and sns indices in normotensive wky rats. BMC physiology 2009, 9:10.

168. Yang X, Schadt EE, Wang S, Wang H, Arnold AP, Ingram-Drake L, Drake TA, Lusis AJ: Tissue-specific expression and regulation of sexually dimorphic genes in mice. Genome Res 2006, 16:995-1004

169. van Nas A, Guhathakurta D, Wang SS, Yehya N, Horvath S, Zhang B, IngramDrake L, Chaudhuri G, Schadt EE, Drake TA, et al: Elucidating the role of gonadal hormones in sexually dimorphic gene coexpression networks. Endocrinology 2009, 150:1235-1249.

170. Maris ME, Melchert RB, Joseph J, Kennedy RH: Gender differences in blood pressure and heart rate in spontaneously hypertensive and Wistar-Kyoto rats. Clin Exp Pharmacol Physiol 2005, 32:35-39.

171. Davidson AO, Schork N, Jaques BC, Kelman AW, Sutcliffe RG, Reid JL, Dominiczak AF: Blood pressure in genetically hypertensive rats. Influence of the $Y$ chromosome. Hypertension 1995, 26:452-459.

172. Ashton N, Balment RJ: Sexual dimorphism in renal function and hormonal status of New Zealand genetically hypertensive rats. Acta Endocrinol (Copenh) 1991, 124:91-97.

173. Yanes LL, Sartori-Valinotti JC, lliescu R, Romero DG, Racusen LC, Zhang H, Reckelhoff JF: Testosterone-dependent hypertension and upregulation of intrarenal angiotensinogen in Dahl salt-sensitive rats. Am J Physiol Renal Physiol 2009, 296:F771-779.

doi:10.1186/2042-6410-3-7

Cite this article as: Sandberg and Ji: Sex differences in primary

hypertension. Biology of Sex Differences 2012 3:7.

\section{Submit your next manuscript to BioMed Central and take full advantage of:}

- Convenient online submission

- Thorough peer review

- No space constraints or color figure charges

- Immediate publication on acceptance

- Inclusion in PubMed, CAS, Scopus and Google Scholar

- Research which is freely available for redistribution

Submit your manuscript at www.biomedcentral.com/submit 